\title{
Enhanced Properties of a Benzimidazole Benzylpyrazole Lysine Demethylase Inhibitor: Mechanism-of-Action, Binding Site Analysis, and Activity in Cellular Models of Prostate Cancer
}

David M. Carter, Edgar Specker, Piotr H. Małecki, Jessica Przygodda, Krystyna Dudaniec, Manfred S. Weiss, Udo Heinemann,* Marc Nazaré,* and Ulrich Gohlke

Cite This: J. Med. Chem. 2021, 64, 14266-14282

Read Online

ACCESS | Llll Metrics \& More | 回 Article Recommendations | sl supporting Information

ABSTRACT: Jumonji domain-containing lysine demethylase (KDM) enzymes are encoded by genes of the KDM superfamily. Activities of the KDM4 subfamily promote aggressive phenotypes associated with prostate cancer (PCa). Previously, we discovered a benzimidazole pyrazole molecule that inhibited KDM4 isoforms with properties tractable for development. Here, we demonstrate that a benzyl-substituted variant of this inhibitor exhibits improved potency in biochemical assays, is cell-permeable, and kills PCa cells at low micromolar concentrations. By X-ray crystallography and kinetics-based assays, we demonstrate that the mechanism of inhibition is complex, proceeding via competition with the enzyme for binding of active-site $\mathrm{Fe}^{2+}$ and by populating a distal site on the

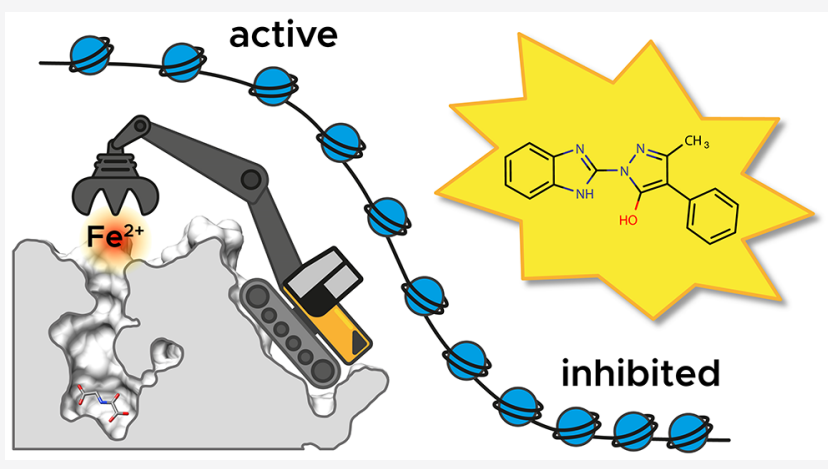
enzyme surface. Furthermore, we provide evidence that the inhibitor's cytostatic properties arise from direct intracellular inhibition of KDM4 enzymes. PCa cells treated with the inhibitor exhibit reduced expression of genes regulated by the androgen receptor, an outcome accompanied by epigenetic maintenance of a heterochromatic state.

\section{INTRODUCTION}

Over the last several years, lysine demethylase (KDM) enzymes have gained recognition as targets for drug-mediated therapy against various diseases and ailments ranging from cancer, ${ }^{1}$ inflammation, ${ }^{2}$ and viral infection. ${ }^{3-5}$ Originally, and within a clinical context of prostate cancer $(\mathrm{PCa})$, the flavin adenosine dinucleotide (FAD)-dependent KDM1 demethylase was demonstrated to directly interact with nuclear-localized androgen receptor (AR), ${ }^{6}$ stimulating gene transcription by removing repressive mono- and di-methyl epigenetic marks at lysine 9 of histone H3. Subsequent reports expanded upon histone demethylation activities by demonstrating that isoforms of the KDM4 subfamily (KDM4A, KDM4B, KDM4C, and KDM4D) also interact with the nuclear-localized $\mathrm{AR}^{7-9}$ and stimulate gene transcription by removing repressive diand tri-methyl epigenetic marks at lysine 9 of histone $\mathrm{H} 3$ (the latter of which is denoted here as $\mathrm{H} 3 \mathrm{~K} 9 \mathrm{me} 3$ ). Since these discoveries, several additional KDMs have been identified, whose collective activities are now recognized as important mediators of disease progression. Accordingly, many KDMs are current targets of small-molecule discovery campaigns with hopes that inhibitors found therein may prove to be of therapeutic value. ${ }^{1-5}$

The KDM4 subfamily (KDM4A-E) belongs to a larger superfamily of enzymes referred collectively as the jumonji $\mathrm{C}$
(JmjC) domain-containing $\mathrm{KDMs}$ (denoted here as JmjCKDMs). All members of this superfamily utilize $\mathrm{Fe}^{2+}$ as a cofactor and $\alpha$-ketoglutarate [ $\alpha$-KG or 2-oxoglutarate (2OG)] as a cosubstrate to demethylate specific lysine residues within core histones of nucleosomal assemblies. ${ }^{10}$ These activities are believed to stimulate gene transcription by participating in a complex process of chromatin reorganization, ultimately yielding an expanded state of euchromatin, opened to initiate gene transcription. In doing so, nuclear transcription factors gain access to promoters of genes they regulate, thereby initiating general transcription. Some of these KDM-regulated genes act as oncogenes, endowing cancer cells with proliferative advantage. ${ }^{11}$

To date, several inhibitors targeting JmjC-KDMs have been described (reviewed extensively in refs 12-15). Most of these inhibitors competitively interfere with substrate turnover by acting as inert $\alpha$-KG surrogates. Notable exceptions include

Received: April 16, 2021

Published: September 23, 2021 
JIB-04, which was described to inhibit the KDM4 subfamily via a non-competitive mechanism with respect to $\alpha$-KG, ${ }^{16}$ as well as peptidomimetics designed to mimic the histone substrate. ${ }^{17}$ Previously, we reported the results of a high-throughput screen (HTS) against the human KDM4E isoform and the identification of a novel benzimidazole-pyrazole scaffold with properties tractable for further development. ${ }^{18}$ In addition to these properties, the scaffold was notable in that it shared similarities with two compounds developed as competitive inhibitors of other $\mathrm{Fe}^{2+} / \alpha$-KG-dependent enzymes. ${ }^{19,20}$ However, although this benzimidazole pyrazole compound functioned in orthogonal, biochemical-based assays of KDM4 activity, it exhibited limited anti-proliferative activity in cellbased models of PCa and KDM4 function.

Here, we report on efforts to enhance the properties of this scaffold, resulting in a compound with 10-fold increased potency relative to the original HTS hit, and via a complex mechanism of action, coupling a competition with the enzyme for active-site $\mathrm{Fe}^{2+}$ with binding to a distal, as-of-yet undescribed site on the enzyme's surface. We demonstrate that the improved scaffold is cell-permeable and provide several lines of evidence for the inhibition of KDM4 enzymes in PCa cell lines. Importantly, inhibition of intracellular KDM4 activity coincides with the accumulation of the repressive $\mathrm{H} 3 \mathrm{~K} 9$ me3 epigenetic mark and down-regulation of genes expressed during PCa progression. These results provide the proof of principle that the molecular scaffold merits further investigation and optimization as an in vivo KDM4-specific inhibitor.

\section{RESULTS}

Enhanced Efficacy of the Benzimidazole Pyrazole Scaffold. Our previous efforts ${ }^{18}$ identified molecule CBN 209350, a novel benzimidazole pyrazole-based inhibitor of recombinant KDM4E, from a high-throughput screen. This compound inhibited equally all members of the KDM4 family and exhibited modest selectivity over other JmjC-KDMs including KDM2A and PHF8. We hypothesized that the compound inhibited these enzymes in part by chelating activesite $\mathrm{Fe}^{2+}$ and envisioned a similar mode of binding as observed in two crystal structures of inhibitor-bound KDM4A (PDB-ID $4 \mathrm{URA}^{21}$ and PDB-ID 4GD4 ${ }^{22}$ ).

Notably absent from CBN 209350, but present in several other competitive JmjC-KDM inhibitors, were sidechains capable of forming canonical hydrogen bonds with residues comprising the enzyme's active site (described extensively in ref 15). The importance of this H-bonding motif is underscored by several inhibitors possessing either a carboxylate function $^{12-15}$ or a similar bioisostere ${ }^{23}$ and which mimic the terminal ethyl carboxylate found in the cosubstrate, $\alpha$-KG. We hypothesized that a similarly positioned carboxylic function in the pyrazole scaffold might mediate such interactions. To test this, an optimization campaign was initiated by synthesizing derivatives of CBN 209350 (denoted hereafter as compound 1, Table 1) with functionalized sidechains containing carboxyl moieties or ester variants thereof. The initial design strategy (compounds 2-6, Table 1 , Figures 1 and S1) incorporated these functionalized sidechains at positions R1 and R2 of the original scaffold, so that they might participate in canonical $\mathrm{H}$-bonding interactions with JmjC-KDM active-site residues Tyr132 and Lys206 (human KDM4A numbering). These and all further compounds were then tested as inhibitors of KDM4E, a
Table 1. Synthetic Derivatives of a Benzimidazole PyrazoleBased JmjC-KDM Inhibitor

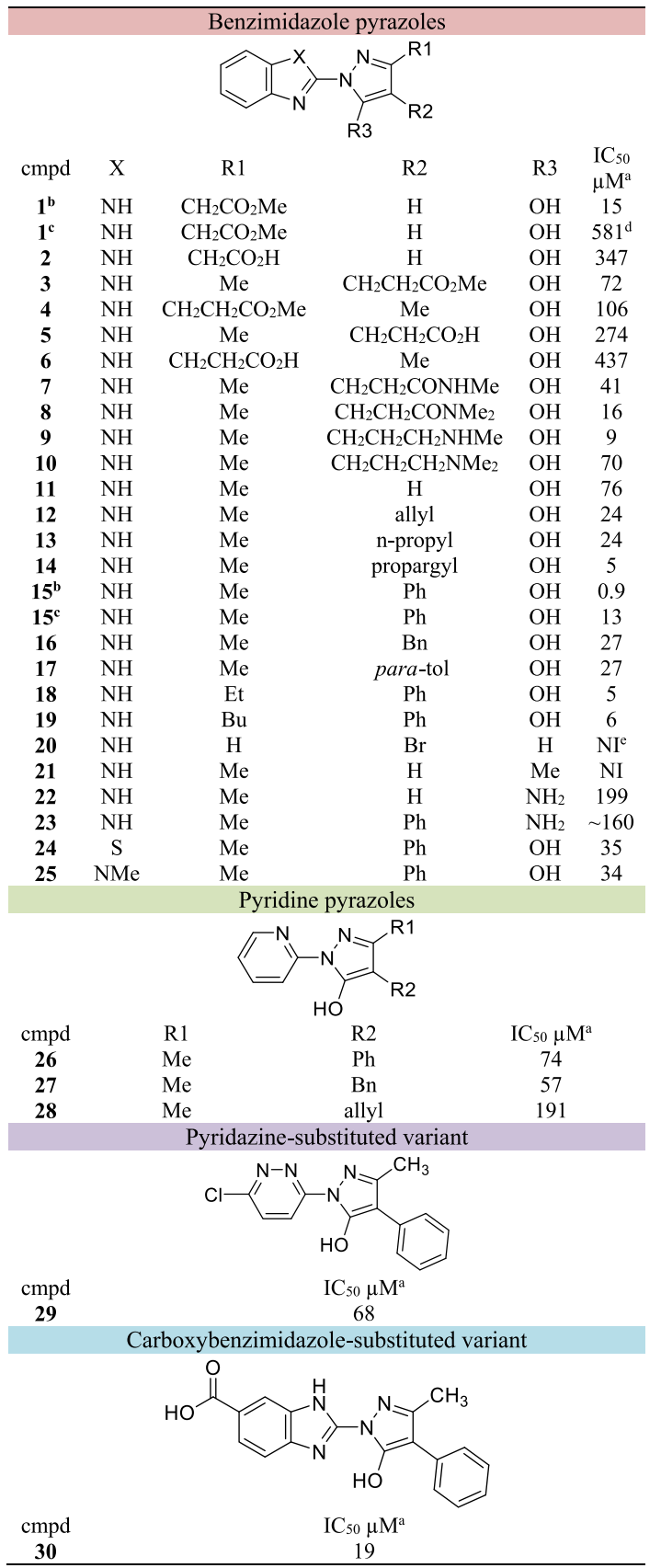

${ }^{a}$ Values calculated from kinetic data using the $\log$ (inhibitor) vs response-variable slope inhibition model in GraphPad Prism. See Table S1 for full fitting statistics. ${ }^{b}$ Values from the FDH-based assay. ${ }^{c}$ Values from the CTH ELISA-based assay. ${ }^{d}$ Data reproduced from Carter et al. ${ }^{18}$ : values of $\mathrm{IC}_{50}=12.5$ and $800 \mu \mathrm{M}$ when fit to a biphasic inhibition model. ${ }^{e}$ No inhibition seen at the highest concentration of inhibitor tested.

model isoform of KDM4 enzymes, which by our handling displayed the greatest activity in biochemical assays.

Compound synthesis proceeded via condensation of different 2-hydrazineyl-1 $H$-benzimidazoles and $\beta$-keto-esters substituted at the 2- and 3-positions (Scheme 1). Longer sidechains of $\beta$-keto-esters at the 3-position were synthesized by an aldol-reaction between methyl-phenylacetate and corresponding aldehydes, followed by Swern oxidation or 


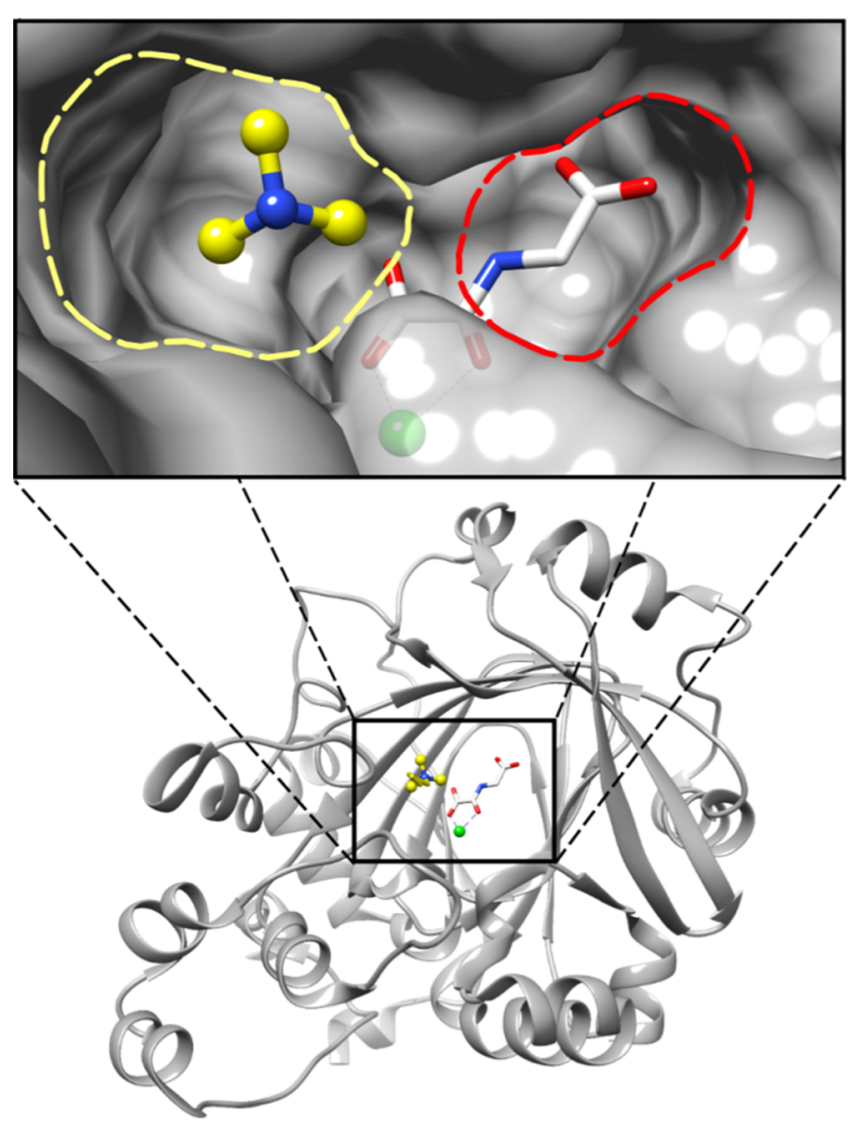

Figure 1. Binding-site regions targeted in JmjC-KDM active sites. The catalytic domain of human KDM4A is depicted in cartoon representation in the bottom figure (PDB code $4 \mathrm{~V} 2 \mathrm{~V}$ ); an activesite close-up is enlarged in the box at the top and depicted in gray surface representation. The cosubstrate $\alpha-\mathrm{KG}$ is depicted in stick representation and colored by atom. The tri-methylated epsilon nitrogen moiety of lysine 9 within the $\mathrm{H} 3 \mathrm{~K} 9$ histone side-chain is depicted in ball-and-stick representation and colored by atom. Activesite $\mathrm{Fe}^{2+}$ is depicted as a green sphere. The region outlined by the red dashed line represents active-site regions targeted by carboxysubstitutions within the inhibitor scaffold (compounds 1-6 and 30). The region outlined by the yellow dashed line represents activesite regions targeted by substituted amines within the inhibitor scaffold (compounds 7-10).

oxidation with the Dess-Martin reagent. This condensation resulted initially in the formation of 2 - $(1 H$-benzimidazol-2-yl)2,4-dihydro-3H-pyrazol-3-one derivatives, which in some cases were detected as intermediates. However, under reflux in $\mathrm{EtOH}$, the more stable aromatic $1-(1 H$-benzo $[d]$ imidazol-2yl)- $1 H$-pyrazol-5-oles were identified and isolated as the final products.

Surprisingly, compounds 2-6 were less potent than the resynthesized HTS hit (compound $\mathbf{1} ; \mathrm{IC}_{50}=15 \mu \mathrm{M}$, Table 1). Moreover, the less polar ester derivatives exhibited greater potencies than their free-acid counterparts (Table 1, compare compound 1, $\mathrm{IC}_{50}=15 \mu \mathrm{M}$, with compound 2, $\mathrm{IC}_{50}=347$ $\mu \mathrm{M}$; compound $3, \mathrm{IC}_{50}=72 \mu \mathrm{M}$, with compound $\mathbf{5}, \mathrm{IC}_{50}=$ $274 \mu \mathrm{M}$; and compound 4, $\mathrm{IC}_{50}=106 \mu \mathrm{M}$, with compound 6, $\left.\mathrm{IC}_{50}=437 \mu \mathrm{M}\right)$.

Outside of the canonical H-bonding interactions by which $\alpha$-KG surrogates participate, crystal structures of $\mathrm{KDM}_{4} \mathrm{~A}^{24}$ with bound synthetic methyl-lysine peptides (PDB IDs 2OT7, 2OQ6, 2OX0) revealed additional recognition motifs exploit- able by rational inhibitor design. For example, the positively charged tri-methyl nitrogen from the lysine sidechain of a H3derived peptide ( $\mathrm{H} 3 \mathrm{~K} 9 \mathrm{me} 3$ ) forms cation $-\pi$ interactions with residue Tyr175 and possibly Tyr177 in the KDM4A substratebinding pocket. ${ }^{24} \mathrm{We}$ therefore considered that incorporation of a substituted amino sidechain into compound 1 might occupy a similar space in KDM4E, contributing toward enhanced potency (Figure 1). In total, four compounds were synthesized and assessed for inhibitory efficacy (Table 1, compounds 7-10, Figure S2). Initially, compound 5 was amidated with methylamine and dimethylamine to yield compounds $7\left(\mathrm{IC}_{50}=41 \mu \mathrm{M}\right)$ and $8\left(\mathrm{IC}_{50}=16 \mu \mathrm{M}\right)$; both compounds inhibited KDM4E with greater potency compared to the corresponding ester (compound 5, $\mathrm{IC}_{50}=72 \mu \mathrm{M}$ ). Compounds 7 and $\mathbf{8}$ were then further reduced with a borane dimethylsufide complex to yield terminal mono- and disubstituted amines 9 and 10. Reduction of compound 7 to 9 $\left(\mathrm{IC}_{50}=9 \mu \mathrm{M}\right)$ enhanced KDM4E inhibition, although with a potency similar to the original resynthesized HTS hit. Conversely, reduction of compound 8 to $10\left(\mathrm{IC}_{50}=70 \mu \mathrm{M}\right)$ weakened the potency of KDM4E inhibition.

Taken together, these results indicated that less polar ester and amide variants are more potent KDM4E inhibitors than their free carboxylic acid counterparts. To expand upon this, compounds 11-15 were generated and a progression toward greater potency was observed as the sidechain at position R2 became less polar (Table 1, Figure S3). In the absence of a sidechain at this position (compound 11), the scaffold exhibited an $\mathrm{IC}_{50}$ of $76 \mu \mathrm{M}$. The addition of allyl and alkyl sidechains at this position (compounds 12 and 13, respectively) afforded similar increases in potency $\left(\mathrm{IC}_{50}\right.$ values of $24 \mu \mathrm{M}$ for both compounds). However, potency increased further upon introduction of an alkyne sidechain at this position (compound 14; $\mathrm{IC}_{50}=5 \mu \mathrm{M}$ ) and reached its highest potency upon introduction of an aromatic ring (compound 15; $\mathrm{IC}_{50}=871 \mathrm{nM}$, Figure 2A).

Given the notable preference for nonpolar, electron-rich sidechains at position R2, we further assessed whether the length of such substitutions influenced the potency of KDM4E inhibition (Table 1, compounds 16-17, Figure S4). Extension of the benzyl sidechain (compound 16; $\mathrm{IC}_{50}=27 \mu \mathrm{M}$ ) decreased the potency compared to that of compound 15, as did the addition of a methyl group para to the benzyl-pyrazole conjugation (compound 17, $\mathrm{IC}_{50}=27 \mu \mathrm{M}$ ). Expanding upon this, whether incorporation of additional nonpolar sidechains into compound $\mathbf{1 5}$ affected inhibitor potency (Table 1, compounds 18-19, Figure S4) was then assessed. Potency diminished slightly when ethyl or butyl sidechains were introduced at position R1 next to the favored benzyl substitution (compounds 18 and 19; $\mathrm{IC}_{50}$ values of 5 and 6 $\mu \mathrm{M}$, respectively).

The role of the hydroxyl moiety attached to the pyrazole ring was also characterized (Table 1, compounds 20-23, Figure S5). Accordingly, neither a brominated derivative of the original scaffold lacking this hydroxyl group (compound 20) nor a methyl-substituted variant, rabenzazole (compound 21), inhibited KDM4E at concentrations up to $100 \mu \mathrm{M}$. Similarly, an amino analogue (compound 22) exhibited weakened potency $\left(\mathrm{IC}_{50}=199 \mu \mathrm{M}\right)$ relative to its hydroxylated variant (compound 11, $\mathrm{IC}_{50}=76 \mu \mathrm{M}$ ), and compound 23, an aminated variant of compound 15, also exhibited weakened potency $\left(\mathrm{IC}_{50} \sim 160 \mu \mathrm{M}\right)$. Taken together, these data indicated that the pyrazole hydroxyl moiety is an essential 
Scheme 1. General Synthesis of Benzimidazole Pyrazoles

$$
\begin{array}{ll}
\mathrm{X}=\mathrm{NH}, \mathrm{NMe} & 15 \mathrm{R} 1=\mathrm{Me}, \mathrm{R} 2=\mathrm{Ph}, \mathrm{X}=\mathrm{NH} \\
\mathrm{R} 1=\mathrm{Me}, \mathrm{Et} & \mathrm{R} 1=\mathrm{Me}, \mathrm{R} 2=\mathrm{Bn}, \mathrm{X}=\mathrm{NH} \\
\mathrm{R} 2=\mathrm{Ph}, \mathrm{Bn} & \mathrm{R} 1=\mathrm{Rt}, \mathrm{R} 2=\mathrm{Ph}, \mathrm{X}=\mathrm{NH} \\
\mathrm{25} \mathrm{R} 1=\mathrm{Me}, \mathrm{R} 2=\mathrm{Ph}, \mathrm{X}=\mathrm{NMe}
\end{array}
$$

Conditions and reagents: a) EtOH, reflux, $2 \mathrm{~h}$

Detailed synthetic pathway of compounds 5 and 9

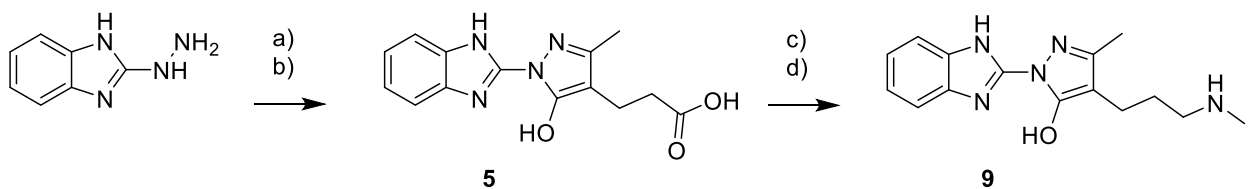

Conditions and reagents: a) dimethyl 2-acetylglutarate, MeOH, reflux, 2h, b) THF, 1M LiOH, RT, 30 min, c) DMF, HOBt, EDC, DIPEA, methylamine, RT, 30 min, d) $\mathrm{BH}_{3}$ in complex with $\mathrm{Me}_{2} \mathrm{~S}$, DCM/THF $1: 1$, RT, $1 \mathrm{~h}$.

Detailed synthetic pathway of compound 19

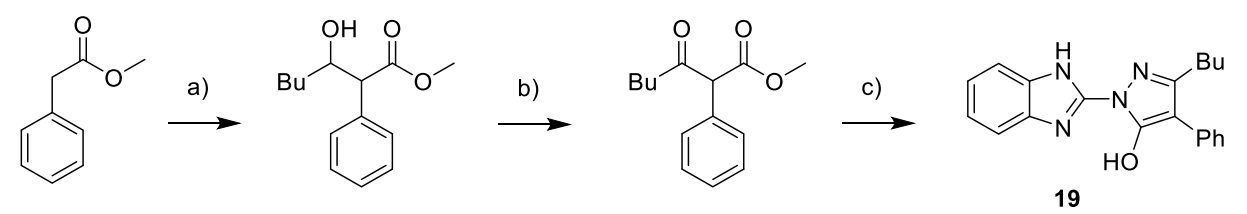

Conditions and reagents: a) THF, $-78^{\circ} \mathrm{C}$, LDA, valeraldehyde, $30 \mathrm{~min}$, then RT, $\left.30 \mathrm{~min}, \mathrm{~b}\right)$ Swern conditions: DCM, DMSO, $-78^{\circ} \mathrm{C}$, $\mathrm{SO}_{2} \mathrm{Cl}_{2}$, then methyl 3-hydroxy-2-phenylheptanoate, $\mathrm{NEt}_{3}, 10 \mathrm{~min}$ at $\left.-78^{\circ} \mathrm{C}, \mathrm{RT}, 1 \mathrm{~h}, \mathrm{c}\right)(1 \mathrm{H}$-1,3-benzimidazol-2-yl $)$ hydrazine, EtOH, reflux, $2 \mathrm{~h}$.

determinant underlying the compounds with enhanced inhibitory efficacies.

Previously, we hypothesized that inhibition of KDM4 enzymes by compound $\mathbf{1}$ proceeds in part via chelation of active-site $\mathrm{Fe}^{2+}$ by the bidentate heterocyclic nitrogen atoms embedded within the scaffold. ${ }^{18}$ To characterize metal chelation, two derivatives of compound 15 were generated (Table 1, Figure S6) which lack tautomerism in the benzimidazole, including compound $24\left(\mathrm{IC}_{50}=35 \mu \mathrm{M}\right)$, which replaces the benzimidazole $\mathrm{NH}$ moiety with a sulfur atom, and compound $25\left(\mathrm{IC}_{50}=34 \mu \mathrm{M}\right)$, which methylates the $\mathrm{NH}$ moiety. Both substitutions reduced potency compared to compound 15. Although nucleophilicity between 15 and 25 is similar, the conformation might be influenced by steric hindrance between the pyrazole ring's methyl and hydroxyl groups, leaving $\mathbf{2 5}$ in a nonplanar conformation detrimental for $\mathrm{Fe}^{2+}$ chelation. For compound 24, the sulfur atom might partly contribute as an alternative $\mathrm{Fe}^{2+}$ chelation motif. Although sulfur-containing molecules are known chelating agents, sulfur atoms in heteroaromatic rings have a poor coordinating ability due to the pseudo aromatic nature of the ring, causing the lone pair to be less available for donation and the $\pi$-orbitals less capable of accepting electrons from a metal.

To characterize the contribution of the scaffold's benzimidazole moiety toward potency of KDM4E inhibition, it was exchanged (Scheme 2, Table 1, Figure S7) with a pyridine (compounds 26-28; Table 1, $\mathrm{IC}_{50}$ values $=74,57$, and 191 $\mu \mathrm{M}$, respectively) or with a 3-chloro pyridazine (compound 29; Table $1, \mathrm{IC}_{50}=68 \mu \mathrm{M}$ ), while leaving the favored pyrazole substitutions as found in compounds 12,15 , and $16\left(\mathrm{IC}_{50}\right.$ values $=24 \mu \mathrm{M}, 871 \mathrm{nM}$, and $27 \mu \mathrm{M}$, respectively). Notably, all variants were less potent than the respective benzimidazoles with a qualitative agreement between $\mathrm{IC}_{50}$ rankings derived from the phenyl pyrazole substitution. Taken together, these data indicated that inhibitor potency is not solely dependent on the nature of the heterocycle as long as it contains an aromatic nitrogen atom for the bidentate chelation motif.

Finally, whether modifications such as a carboxylic acid functional group attached to the benzimidazole moiety affected inhibitor potency were characterized. Our reasoning originated from a hypothesis that the initial position of the carboxylic acid on the pyrazole moiety (i.e., the R1 and R2 scaffold positions) was not optimized. Upon rotating by $180^{\circ}$ in the active site, the inhibitor's benzimidazole-substituted carboxylic acid might therefore interact with active side residues Tyr132 and Lys206, leading to strong hydrogen bond interactions. In testing this hypothesis, compound $\mathbf{3 0}$ was synthesized, which inhibited KDM4E with an $\mathrm{IC}_{50}$ value of $20 \mu \mathrm{M}$ (Table 1, Figure S8). Although the potency of $\mathbf{3 0}$ was weakened relative to $\mathbf{1 5}$, its solubility was greatly enhanced, an important feature that was subsequently leveraged in crystallization experiments (discussed below). Taking into consideration all of the SAR data presented above, we concluded that compound $\mathbf{1 5}$ was most improved with respect to the original HTS hit and with several properties warranting further investigation as described below.

Orthogonal Activity of the Optimized Scaffold. As an orthogonal test of enzyme activity, we utilized an ELISA-based method that we developed and described previously. ${ }^{18}$ This assay measures the methylation state of core histones purified from calf thymus, directly as the readout. Concentrationdependent responses were observed when compound 15 was titrated into a solution of $\mathrm{KDM} 4 \mathrm{E}$ prior to histone demethylation. In general, the $\mathrm{IC}_{50}$ measured from this method (13 $\mu \mathrm{M}$, Table 1) agreed within an order of magnitude 
A

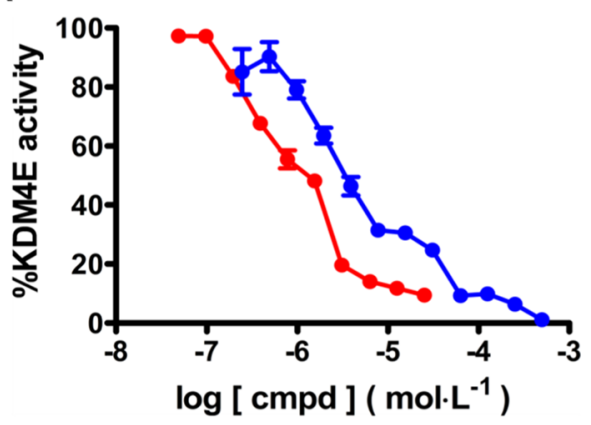

C

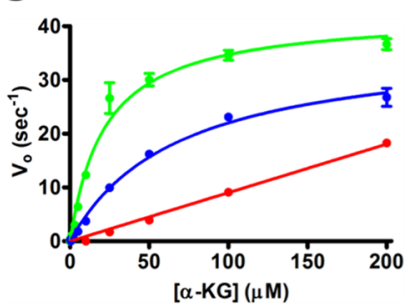

D

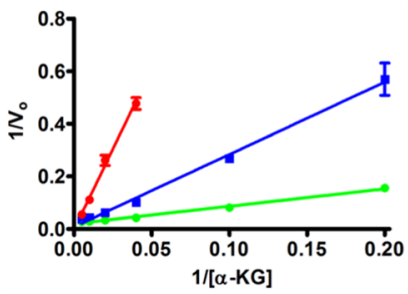

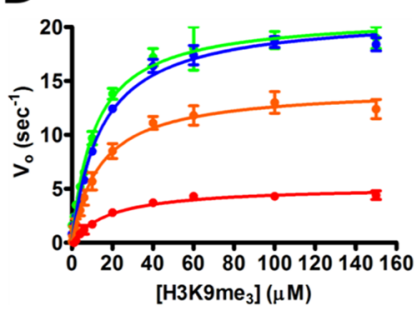

$\left[\mathrm{H} 3 \mathrm{~K} 9 \mathrm{me}_{3}\right](\mu \mathrm{M})$

B

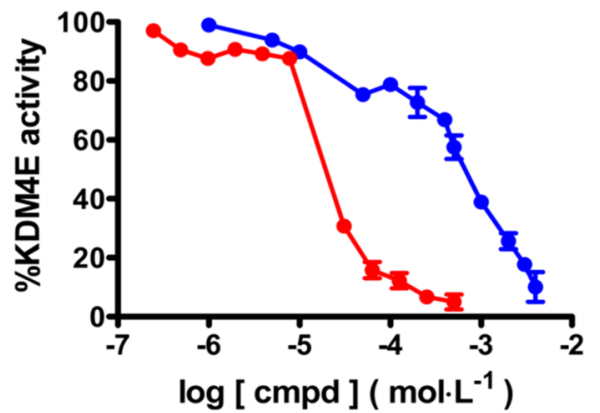

E
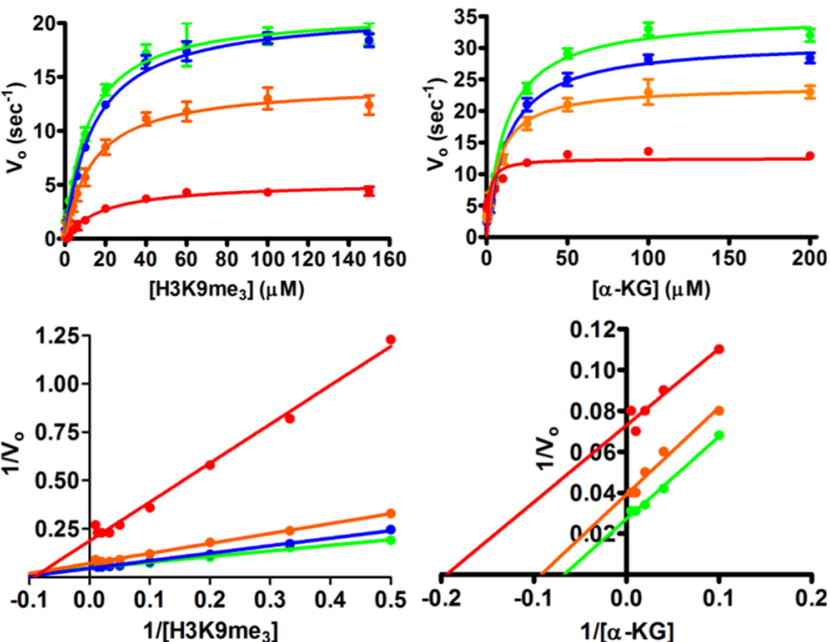

Figure 2. Kinetic analyses of KDM4E inhibition. (A) Fluorescence-based, FDH-coupled KDM4E activity profiles. Comparison of enhanced KDM4E inhibition via compound 15 (red) compared to the initial HTS hit, compound 1 (blue). (B) CTH ELISA-based KDM4E inhibition profiles. Comparison of enhanced KDM4E inhibition by compound 15 (red) relative to the HTS hit, compound 1 (blue). (C) Determining a mechanism of action for the inhibition of KDM4E by 2,4-pyridinedicarboxylic acid (2,4-PDCA). Depicted in the top panel are Michaelis-Menten fits used to determine $K_{\mathrm{m}}$ and $V_{\max }$ values of $\alpha$-KG in the presence of zero (green), $1 \mu \mathrm{M}$ (blue), or $5 \mu \mathrm{M}$ (red) 2,4-PDCA. Double reciprocal plots of these same data are depicted below. (D,E) Determining a mechanism of action for the inhibition of KDM4E by compound 15. Depicted in the top panels are Michaelis-Menten fits used to determine $K_{\mathrm{m}}$ and $V_{\max }$ values for peptide substrate H3K9me3 (panel D) and for $\alpha$-KG (panel E), respectively. Kinetic constants were determined in the presence of either zero (green), $1 \mu \mathrm{M}$ (blue), $5 \mu \mathrm{M}$ (orange), or $10 \mu \mathrm{M}$ (red) compound 15 . Double reciprocal plots of these same data are depicted below each panel accordingly.

Scheme 2. Synthesis of Pyridine Pyrazoles ${ }^{a}$
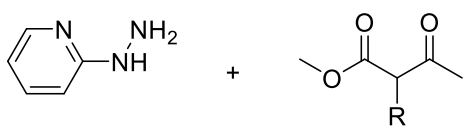

$\mathrm{R}=\mathrm{Ph}, \mathrm{Bn}$, allyl a)

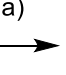

$26 \mathrm{R}=\mathrm{Ph} ; 27 \mathrm{R}=\mathrm{Bn} ; 28 \mathrm{R}=$ allyl

${ }^{a}$ Conditions and reagents: (a) EtOH, reflux, 2 h.

with values measured by the FDH assay, confirming that the derivative is more potent than the original HTS hit (Table 1 and Figure 2B).

Mechanism of Inhibition. The mechanism by which compound 15 inhibits KDM4E was subsequently evaluated using initial velocity data from the $\mathrm{FDH}$ assay to calculate cofactor and substrate-derived values of $K_{\mathrm{m}}$ and $V_{\max }$. These experiments were then repeated to assess how the kinetic constants changed in the presence of an inhibitor. In an initial control experiment, whether compound $\mathbf{1 5}$ inhibits the FDH coupling enzyme was assessed. As expected, neither the original HTS hit, nor compound 15, inhibited FDH in the concentration ranges tested (Figure S9). Next, as an additional control to validate the experimental setup, we assessed how KDM4E kinetic constants were affected by the wellcharacterized JmjC-KDM competitive inhibitor, 2,4-PDCA. Accordingly, a competitive inhibition profile was observed in the measured kinetic data with respect to the cofactor, $\alpha$-KG. In the absence of the inhibitor, an $\alpha$-KG-dependent $K_{\mathrm{m}}$ value of $22 \mu \mathrm{M}$ was calculated, increasing to $69 \mu \mathrm{M}$ in the presence of 2,4-PDCA, as would be expected for a competitive inhibitor (Figure 2C, Table 2). In parallel, $\alpha$-KG-dependent $V_{\max }$ values remained unaffected by the presence of this inhibitor ( 42 and $37 \mathrm{~s}^{-1}$ in the absence and presence of 2,4-PDCA, respectively).

By contrast, results pertaining to the inhibition of KDM4E by compound 15 suggested a complex mechanism of 
Table 2. Kinetic Constants of KDM4E Activity in the Presence of Selected JmjC-KDM Inhibitors

KDM4E cosubstrates and kinetic constants

\begin{tabular}{|c|c|c|c|c|c|}
\hline \multirow[b]{3}{*}{ inhibitor } & \multirow[b]{3}{*}{ test concentration $(\mu \mathrm{M})$} & \multirow{2}{*}{\multicolumn{2}{|c|}{$\alpha-\mathrm{KG}$}} & \multirow{2}{*}{\multicolumn{2}{|c|}{$\mathrm{H} 3 \mathrm{~K} 9 \mathrm{me}_{3}$}} \\
\hline & & & & & \\
\hline & & $K_{\mathrm{m}}(\mu \mathrm{M})^{a}$ & $V_{\max }\left(\mathrm{s}^{-1}\right)^{a}$ & $K_{\mathrm{m}}(\mu \mathrm{M})$ & $V_{\max }\left(\mathrm{s}^{-1}\right)$ \\
\hline \multirow[t]{3}{*}{ 2,4-PDCA } & 0 & $22[16-28]^{b}$ & $42[39-45]$ & $\mathrm{ND}^{c}$ & ND \\
\hline & 1 & $69[52-85]$ & $37[33-41]$ & & \\
\hline & 5 & $\mathrm{NA}^{d}$ & NA & & \\
\hline \multirow[t]{4}{*}{ cmpd 15} & 0 & $12[10-14]$ & $35[33-37]$ & $11[10-13]$ & $21[20-22]$ \\
\hline & 1 & $13[11-15]$ & $31[30-32]$ & $14[13-16]$ & $21[21-22]$ \\
\hline & 5 & $8[6-9]$ & $24[22-25]$ & $14[12-17]$ & $14[14-15]$ \\
\hline & 10 & $2[1-2]$ & $12[11-14]$ & $19[14-24]$ & $5[5-6]$ \\
\hline
\end{tabular}

${ }^{a}$ Determined from the best fits of the Michaelis-Menten model in GraphPad Prism to the initial velocity data. ${ }^{b}$ Values in brackets represent the $95 \%$ confidence interval from the best fits of the Michaelis-Menten Model. ${ }^{c}$ Not determined. ${ }^{d}$ Kinetic data did not reach a point of substrate saturation required for accurate estimations of the kinetic constant.

inhibition, differing with respect to the cofactor/(co)-substrate under investigation. For example, with respect to the H3K9me3 peptide substrate, increasing concentrations of 15 decreased the values of $V_{\max }$ with no effect on this substrate's $K_{\mathrm{m}}$ (Figure 2D, Table 2). This suggests a non-competitive mechanism of inhibition, whereby the binding sites of compound 15 and peptide substrate do not overlap; 15 can bind to the enzyme whether or not the peptide substrate is bound. Conversely, with respect to the $\alpha$-KG cofactor, increasing concentrations of $\mathbf{1 5}$ caused concomitant decreases in both $V_{\max }$ and $K_{\mathrm{m}}$ (Figure 2E, Table 2). These data suggest that compound $\mathbf{1 5}$ is uncompetitive with respect to the $\alpha-\mathrm{KG}$ cosubstrate. One interpretation of this outcome ${ }^{25}$ follows that binding of $\mathbf{1 5}$ favors the formation and stabilization of a KDM4E: $\alpha$-KG complex (decreasing the $K_{\mathrm{m}}$ ) but that this stabilized complex is less primed for substrate turnover (decreasing the $V_{\max }$ ). Although an uncompetitive inhibitory mechanism was not expected, structural investigations into the mode of binding support this interpretation, as further described below.

Crystal Structures of Compounds Bound to KDM4A. The kinetics-based investigations into the mechanism of action (MOA) for the inhibition of KDM4E by 15 suggested a complex mechanism, corroborating challenges faced in the optimization campaign. We therefore sought to further investigate this mechanism by determining crystal structures of the engineered compounds bound to a JmjC-KDM enzyme. In doing so, we succeeded in determining two crystal structures of the KDM4A isoform (PDB IDs 6G5W and 6G5X) with bound derivatives (compounds 26 and 30) of the original HTS hit (Figure 3A-C, Table S2). Both structures revealed an unexpected and novel binding site, not yet described in other inhibitor/fragment-bound structures of JmjC-KDM enzymes. In these structures, the inhibitors were observed bound to an identical surface-exposed binding site on a single KDM4A protein molecule (chain B), close to the intermolecular interface of molecules in the asymmetric unit. By comparison to the apo-enzyme, KDM4A's Phe114 sidechain rotates approximately $90^{\circ}$, translocating its phenyl moiety a distance of $4 \AA$, and opening a small hydrophobic pocket comprising residues Glu118, Ser207, Tyr209, Thr261, Lys259, Phe279, plus the aforementioned Phe114 (Figure $3 \mathrm{~B}, \mathrm{C})$. This pocket is occupied in both structures by the phenyl moieties that constituted favored substitutions within the scaffold's R2 position. In both structures, the ligands' pyrazole moieties interact via $\mathrm{CH}-\pi$ interactions ${ }^{26}$ with KDM4A's Phe114 sidechain ring, while the pyrazole hydroxyl group forms hydrogen bonds with a main-chain $\mathrm{N}$ atom and a hydroxyl group of Thr261. By contrast, distal moieties of both ligands project into the surrounding solvent between both KDM4A protein molecules of the asymmetric unit. These moieties comprise a pyridine ring in compound 26 and a benzimidazole in compound 30 . In the latter case, the benzimidazole aligns linearly with a guanidine moiety of Arg218 from a KDM4A protein in chain A with a distance of about $3.5 \AA$, suggesting a cation $-\pi$ interaction. Conversely, the pyridine moiety of compound $\mathbf{2 6}$ is not involved in a proteinligand interaction. Importantly, both inhibitors chelate a $\mathrm{Ni}^{2+}$ ion (added to crystallization buffers as an $\mathrm{Fe}^{2+}$ surrogate) whose coordination is completed by a citrate molecule that was present in the crystallization solution (Figure 3B,C).

KDM4 Inhibitor Scaffolds Displace Active-Site Metal lons. Our previous kinetics-based mechanistic evaluations using KDM4E and compound $\mathbf{1 5}$ suggested a complex MOA that was non-competitive with respect to $\alpha$-KG. Although this outcome was unexpected, the crystal structures presented here also revealed that inhibitors based on the original HTS scaffold can still interact with $\mathrm{Fe}^{2+}$ and that this property is an essential determinant of inhibition. Although both structures revealed inhibitor molecules bound to KDM4A's distal surface-exposed hydrophobic pocket, the active sites remained occupied by $\mathrm{Ni}^{2+}$ ions, together with citrate molecules from the crystallization buffer. The presence of active-site $\mathrm{Ni}^{2+}$ was not surprising since saturation of the enzyme's active site necessitated the soaking of crystals in solutions containing a molar excess of this ion. Because KDM4A crystals are fragile, require manipulation in cold-room conditions, and frequently suffer from loss of diffraction quality, surrogate KDM4 isoforms were considered for subsequent crystallographic analysis. Accordingly, the KDM4D isoform crystallizes at room temperature and under conditions that can be altered, often with no apparent loss in diffraction. For these reasons, KDM4D crystals were soaked in a solution containing $\mathrm{Ni}^{2+}$ ions at molar excess, followed by a second soaking in a solution containing the original HTS hit (compound $\mathbf{1}$ alone, without additional $\mathrm{Ni}^{2+}$ ions). Although KDM4D crystals were soaked in the presence of several benzimidazole pyrazole inhibitors, including those identified in KDM4A crystal structures, most soaking experiments led to complete loss of diffraction. However, KDM4D crystals soaked with compound 1, as described above, diffracted up to $1.5 \AA$ resolution. The resulting structure (data not shown) revealed no electron density for the ligand in the active site, nor for the active-site $\mathrm{Ni}^{2+}$ ion. When present, this ion coordinates to KDM4D 


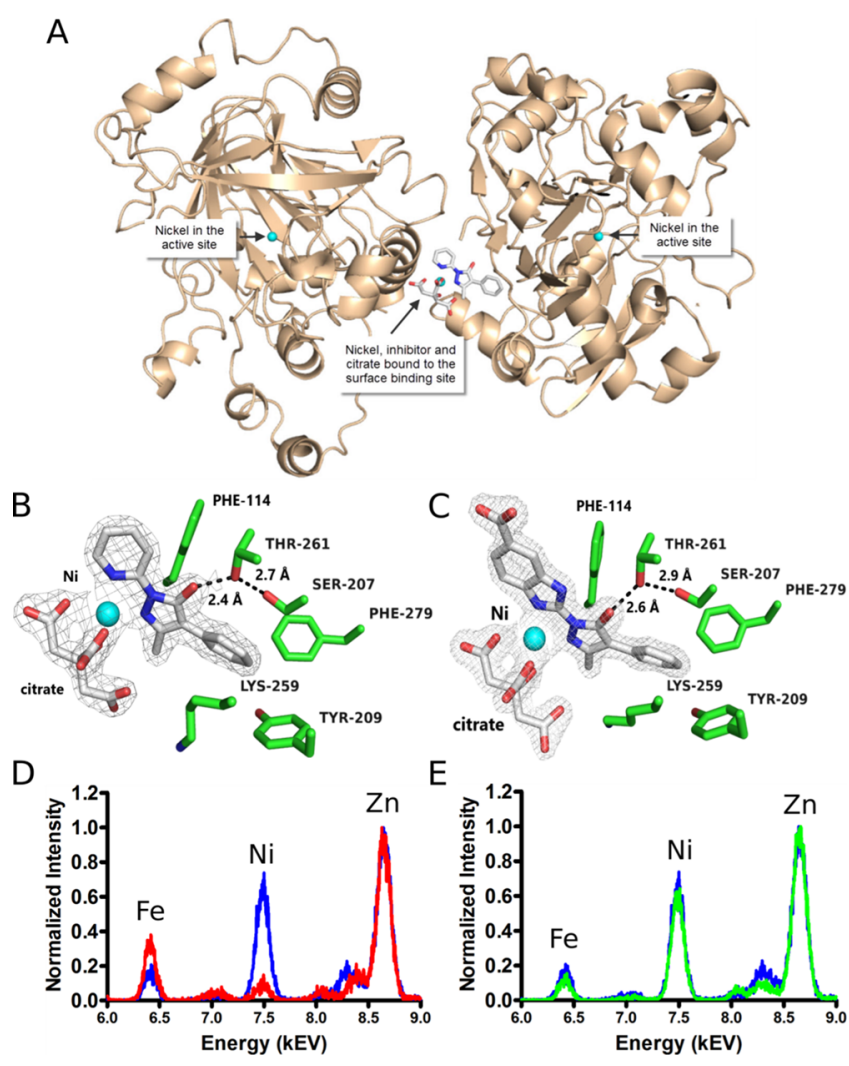

Figure 3. Structural insight into the inhibition of the KDM4 subfamily of enzymes by pyrazole imidazole-based compounds 26 and 30. (A) Crystal structure of KDM4A (ribbon representation) with compound 26 (stick representation) bound between two molecules of the asymmetric unit. Nickel ions are indicated as cyan spheres. A citrate molecule (stick representation) is also shown. (B,C) Detailed views of KDM4A inhibitor binding sites. Electron densities $\left(F_{\mathrm{o}}-F_{\mathrm{c}}\right.$ maps contoured at $1.0 \sigma$ for $\mathbf{2 6}$ and at $1.5 \sigma$ for $\mathbf{3 0}$ ) of the inhibitors bound to the surface of KDM4A are indicated by the mesh. Inhibitor compounds 26 (panel B) and 30 (panel C) are indicated in stick representation along with additionally bound citrate molecules. Sidechains of KDM4A residues (green stick representation) comprising the inhibitor binding site are labeled accordingly. (D,E) Energy-dispersive fluorescence spectra demonstrating the removal of $\mathrm{Ni}^{2+}$ ions from the active sites of KDM4D crystals. Peaks arising from metal ions present in the crystals are labeled accordingly. Crystals were first soaked in a molar excess of $\mathrm{Ni}^{2+}$ ions, and the resulting fluorescence spectra were recorded (blue spectra in panels $\mathrm{D}$ and $\mathrm{E}$ ). These same crystals were then soaked overnight either in a solution containing KDM4 inhibitor compound $\mathbf{1}$ (red spectrum, panel D) or a control solution containing buffer plus DMSO alone (green spectrum, panel E). Disappearance of the $\mathrm{Ni}^{2+}$ peak in inhibitorsoaked crystals indicates the removal of this ion from the protein molecules.

active-site residues His192, Glu194, and His280, with bond distances ranging between 2.1 and $2.2 \AA$. Electron density within this active-site region was generally weak and barely sufficient to model a $\mathrm{Ni}^{2+}$ ion with about $10 \%$ occupancy. Since the magnitude of this signal was too small for modeling into the structure, we omitted it from the final refined model. Instead, a water molecule was modeed, which forms hydrogen bonds with distances of 2.6 and $2.7 \AA$ to KDM4D residues His 192 and Glu194, respectively.

To quantify the presence of $\mathrm{Ni}^{2+}$ ions in KDM4D crystals before and after ligand-soaking experiments, energy-dispersive fluorescence spectra were collected. Peak heights of three replicate measurements were averaged and normalized to a single representative measurement based on the highest observed peak (corresponding to a structural, non-catalytic zinc atom present in all KDM4 enzymes). Although the magnitude of the Ni peak decreased from 0.74 to 0.12 au after soaking with compound $\mathbf{1}$ (Figure 3D), it remained unchanged after soaking with DMSO (Figure 3E, magnitudes of 0.66 and 0.64 before and after soaking with DMSO, respectively). Taken together, these data unequivocally demonstrated that the benzimidazole pyrazole inhibitor is capable of completely removing active-site metal ions, thereby inactivating the enzyme.

Cytotoxicity of the Improved KDM4 Inhibitor. Another goal of the discovery campaign was to increase cellular penetration of the KDM4 inhibitor scaffold in order to assess whether derivatives might inhibit the enzymes in relevant cellular models of PCa. The original scaffold identified in the HTS campaign (compound 1) exhibited only limited activity in cytotoxicity assays $\left(\mathrm{GI}_{50}=410 \mu \mathrm{M}\right.$ against the $\mathrm{LnCaP}$ cell line). ${ }^{18}$ Extending from this, the alamarBlue assay was employed to assess the viability of PCa cells treated with the improved KDM4E inhibitor, compound 15. Accordingly, compound $\mathbf{1 5}$ was found to be more potent than both the parent scaffold (Table 3 and Figure 4A) and ML324, another

Table 3. Cytotoxicity Profiles of Selected KDM4 Inhibitors

\begin{tabular}{|c|c|c|c|c|c|}
\hline \multirow[b]{2}{*}{$\mathrm{cmpd}$} & \multirow[b]{2}{*}{ fitting results } & \multicolumn{4}{|c|}{ cell line } \\
\hline & & $\mathrm{LnCaP}$ & DU145 & PC-3 & $\mathrm{HuPrEC}$ \\
\hline \multirow[t]{6}{*}{1} & $\mathrm{GI}_{50}(\mu \mathrm{M})^{a}$ & 410 & $>1000$ & $>1000$ & $>500$ \\
\hline & $95 \%$ CI $(\mu \mathrm{M})^{b}$ & $375-449$ & $\mathrm{NA}^{g}$ & NA & NA \\
\hline & top $^{c}$ & $101 \%$ & & & \\
\hline & bottom $^{d}$ & $0 \%$ & & & \\
\hline & hill slope $e^{e}$ & -1.5 & & & \\
\hline & residual $f$ & $15 \%$ & $69 \%$ & $79 \%$ & $12 \%$ \\
\hline \multirow[t]{6}{*}{15} & $\mathrm{GI}_{50}(\mu \mathrm{M})$ & 8 & 8 & $>50$ & 26 \\
\hline & $95 \% \mathrm{CI}(\mu \mathrm{M})$ & $7-9$ & $7-10$ & NA & $24-27$ \\
\hline & top & $101 \%$ & $101 \%$ & 100 & 102 \\
\hline & bottom & $8 \%$ & $4 \%$ & NA & $0 \%$ \\
\hline & hill slope & -2.5 & -1.8 & NA & -2.2 \\
\hline & residual & $1 \%$ & $0 \%$ & $27 \%$ & $2 \%$ \\
\hline \multirow[t]{6}{*}{ ML324 } & $\mathrm{GI}_{50}(\mu \mathrm{M})$ & 53 & $\mathrm{ND}^{h}$ & ND & ND \\
\hline & $95 \% \mathrm{CI}(\mu \mathrm{M})$ & $43-64$ & & & \\
\hline & top & 100 & & & \\
\hline & bottom & -5.8 & & & \\
\hline & hill slope & -2.7 & & & \\
\hline & residual & $1 \%$ & & & \\
\hline
\end{tabular}

${ }^{a}$ Values calculated from cell viability data using the $\log$ (inhibitor) vs response-variable slope inhibition model in GraphPad Prism. ${ }^{b}$ Fitting error reported as a $95 \%$ confidence interval. ${ }^{c}$ Highest level of cell viability fit as a variable in the inhibition model. ${ }^{d}$ Lowest level of cell viability fit as a variable in the inhibition model. ${ }^{e}$ Steepness, or hill slope, of the dose-response curve. ${ }^{f}$ Percentage of cell viability remaining at the highest inhibitor concentration tested. ${ }^{g}$ Not applicable given a lack of growth inhibition at the concentration range tested. ${ }^{h}$ Not determined.

cell-permeable JmjC-KDM inhibitor. ${ }^{27}$ The resulting cytotoxicity profiles (Figure 4B) indicated that 15 inhibited the growth of all PCa cell lines tested, including DU145 cells and PC3 cells, plus a non-disease control cell line ( $\mathrm{HuPrEC})$, with similar efficacies and values of $\mathrm{GI}_{50}$ in the range of $8-26 \mu \mathrm{M}$ (Table 3). 


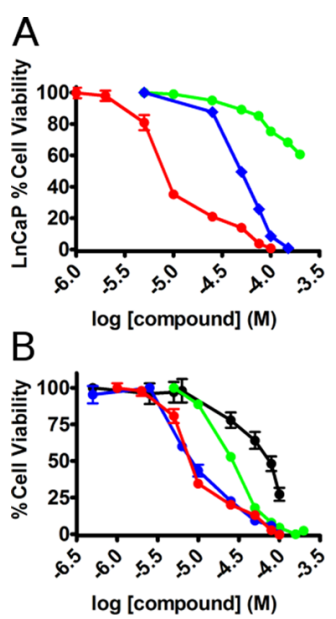

Figure 4. Cytotoxicity profiles of selected KDM4 inhibitors. Prostatederived cell lines were grown in the presence of KDM4 inhibitors, and the resulting viabilities (reported above as percent cell viability) were measured using the alamarBlue assay. (A) $\mathrm{LnCaP}$ cells were treated with increasing concentrations of either compound 1 (green), ML324 (blue), or compound 15 (red). (B) An expanded panel of prostate cancer cell lines was treated with compound $\mathbf{1 5}$ and assessed via the alamarBlue assays as in panel A above. The following cancer cell lines were compared: LnCaP (red), DU145 (blue), and PC3 (black). Human prostate epithelial ( $\mathrm{HuPrEC}$ ) cells (green) were tested as a healthy, non-malignant cell line control.

Inhibition of AR-Dependent Gene Regulation in PCa Cells. Given the measurable cytotoxicity exhibited by $\mathbf{1 5}$ against PCa model cell lines, we sought evidence that this effect was directly mediated by the inhibition of intracellular KDM activity. Since KDM4 enzymes stimulate gene expression, we employed as the first measure, a luciferasebased reporter assay to assess whether intracellular KDM inhibition might also decrease the expression of a luciferase reporter gene. The experimental strategy leveraged ARdependent gene expression, which can be stimulated in ARexpressing cells, including the LnCaP PCa model cell line. ${ }^{28}$ This cell line responds to stimulation with AR ligands, in part by increasing the expression of the clinical biomarker, prostatespecific antigen (PSA). Accordingly, a luciferase-based reporter assay was established by cloning the promoter and enhancer regions of the human PSA gene upstream from the gene encoding firefly luciferase and by transfecting the resulting plasmid into LnCaP cells. Stimulation of transfected $\mathrm{LnCaP}$ cells with the AR antagonist R1881 elicited a robust luminescence signal from the reporter that was slightly, although not significantly, augmented when cells were grown in the presence of $0.5 \%(\mathrm{v} / \mathrm{v})$ DMSO (Figure $5 \mathrm{~A})$. As a positive control for intracellular KDM4 inhibition, cells were treated with $50 \mu \mathrm{M}$ of the cell-permeable inhibitor ML324. As expected, treatment with ML324 caused a significant decrease in luciferase expression, indicating that inhibition of intracellular KDM4 activity reduces AR-dependent gene expression. The effect was even more pronounced when cells were treated with $25 \mu \mathrm{M}$ of the optimized KDM4 inhibitor, compound 15 (Figure 5A), suggesting that this inhibitor mediates its cytotoxic effects at least in part through inhibition of intracellular KDMs.

Down-Regulation of Androgen-Receptor-Dependent Gene Expression in PCa Cells. Given the relatively artificial context of gene expression using a luciferase-based reporter
A

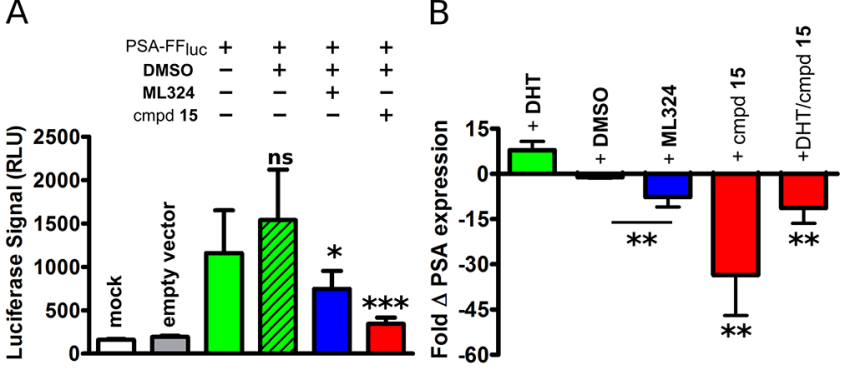

C

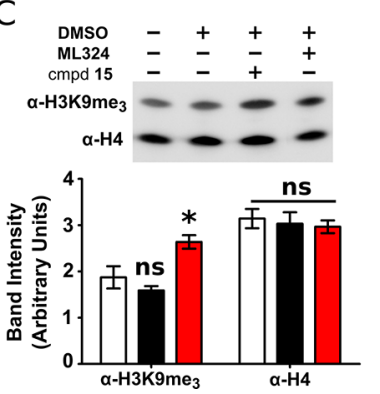

D

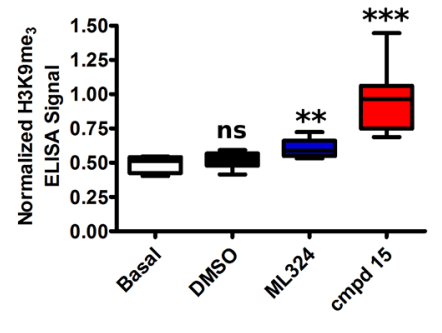

Figure 5. Compound $\mathbf{1 5}$ is active in cellular models of prostate cancer. (A) Compound $\mathbf{1 5}$ inhibits gene expression in a luciferasebased reporter gene assay. Relevant constituents present in each experiment are indicated in the matrix above each bar. Statistical $P$ values from $t$-tests were calculated relative to the reporter signal arising from untreated cells (for DMSO treatment, ns = not significant; for $\mathrm{ML} 324, * P=0.0253$; for compound $15, * * * P<$ $0.0001)$. (B) Compound 15 inhibits endogenous expression of PSA in $\mathrm{AR}^{+} \mathrm{LnCaP}$ cells. Statistical $P$ values were calculated relative to the signal arising from PSA expression in cells treated with DMSO alone (for ML324, **P $=0.0058$; for compound 15, $* * P=0.0078$; for compound 15 plus DHT, $* * P=0.0021$ ). (C) Chromatin extracted from $\mathrm{LnCaP}$ cells treated with compound 15 exhibits significantly higher levels of the H3K9me3 epigenetic mark compared to cells treated with DMSO alone. Indicated at the top of panel $\mathrm{C}$ is a representative western blot detecting the H3K9me3 epigenetic mark (top bands) relative to static levels of a non-epigenetic epitope within histone H4 (bottom bands). Relevant constituents present in each experiment are indicated in the matrix above the blot. Depicted at the bottom of panel $\mathrm{C}$ are the densitometric readings of the blot. Bar heights measure mean signals from three biological replicates of either untreated cells (white), DMSO-treated cells (black), or compound 15-treated cells (red). Statistical $P$ values from $t$-tests were calculated relative to the signal arising from untreated cells (for DMSO, ns = not significant; for compound $15, * P=0.0189$ ). No significant differences were measured in the $\mathrm{H} 4$ epitope. (D) Nucleosomal preparations from LnCaP cells treated with membrane-permeable KDM4 inhibitors exhibit significantly higher levels of the H3K9me3 epigenetic mark (normalized to a static histone $\mathrm{H} 4$ epitope), compared to treatment with DMSO alone. Statistical $P$ values were calculated relative either to the signal arising from cells grown under basal conditions (for DMSO, ns = not significant) or relative to the signal arising from cells grown in the presence of DMSO (for ML324, $* * P=0.0080$; for compound $15, * * * P=0.0007)$.

system, we performed qPCR-based experiments to further assess, in a more native cellular context, whether treatment of LnCaP cells with compound $\mathbf{1 5}$ affected AR-dependent PSA gene expression. This technology has been successfully used in the past to assess relative changes in PSA biomarker expression in the $\mathrm{LnCaP}$ cell line. ${ }^{29}$ As a positive control, $\mathrm{LnCaP}$ cells, grown in androgen-depleted media, were treated with the AR agonist, dihydrotestosterone (DHT). As expected, this treatment stimulated AR-mediated transcription of PSA (Figure 
Scheme 3. Schematic Overview of the Investigated Structure-Activity Relationship ${ }^{a}$

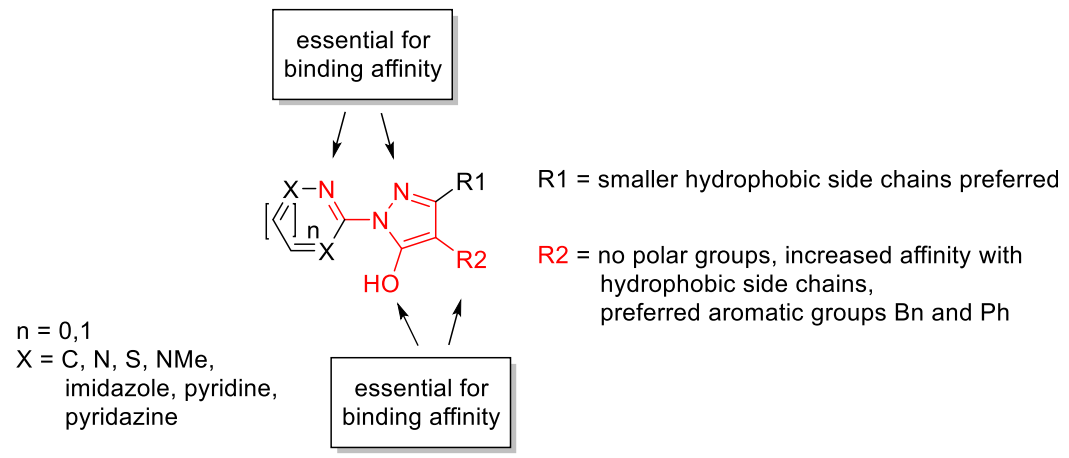

${ }^{a}$ Regions highlighted in red constitute an essential structural framework for binding activity.

5B). Conversely, treatment of cells with $25 \mu \mathrm{M}$ of $\mathrm{KDM} 4$ inhibitor 15 caused a highly significant decrease in PSA expression. Interestingly, this effect was diminished but still significant when cells were cotreated with DHT and 15. By contrast, a weaker effect was observed when cells were treated with $100 \mu \mathrm{M}$ KDM4 inhibitor ML324 or with DMSO alone.

Chromatin from PCa Cells Treated with Compound 15 Remains in a Silenced and Heterochromatic Epigenetic State. Whether compound 15-mediated decreases in gene expression occurred alongside maintenance of a transcriptionally silent heterochromatic state was assessed as the third line of evidence for intracellular KDM4 inhibition. To test this, two immunochemical techniques were employed, involving detection of the H3K9me3 epigenetic state. First, purified chromatin was examined from untreated $\mathrm{LnCaP}$ cells, from cells treated with $0.5 \%(\mathrm{v} / \mathrm{v}) \mathrm{DMSO}$, and from cells treated with $25 \mu \mathrm{M}$ compound 15. No significant differences in the $\mathrm{H} 3 \mathrm{~K} 9 \mathrm{me} 3$ epigenetic mark were discernible by western blot analysis between healthy cells and DMSO-treated cells relative to a static non-epigenetic motif within histone $\mathrm{H} 4$ used as a loading control. By contrast, treatment with $\mathbf{1 5}$ caused a significant increase in $\mathrm{H} 3 \mathrm{~K} 9 \mathrm{me} 3$ abundance as would be expected if intracellular KDM enzymes were inhibited (Figure $5 \mathrm{C})$.

To corroborate this, nucleosomal ELISA (nu-ELISA) experiments were performed, described originally to evaluate the effects of HDAC inhibitors on global levels of histone acetylation. $^{30}$ Our previous use of this method ${ }^{18}$ further demonstrated its utility in examining global states of chromatin methylation. We reported that the treatment of both $\mathrm{LnCaP}$ and DU145 cells with either DMSO or the original HTS hit (compound 1) did not alter chromatin methylation relative to untreated cells. Conversely, treatment with the cell-permeable KDM4 inhibitor, ML324, caused significant increases in chromatin methylation, consistent with the maintenance of a heterochromatin state. Extending from these previous observations, treatment of $\mathrm{LnCaP}$ cells with $25 \mu \mathrm{M}$ of the improved KDM4 inhibitor, compound 15, like ML324, caused significant increases in the amounts of the H3K9me3 epigenetic mark in histone $\mathrm{H} 3$ relative to static non-epigenetic motifs within histone H4 (Figure 5D). Similar nu-ELISA results were observed when the DU145 cell line was cultured under identical treatment conditions as outlined above (Figure S10). Taken together, data from chromatin western-blotting experiments and Nu-ELISA analyses both indicated that PCa cells treated with cell-permeable KDM4 inhibitors ML324 and compound 15 exhibited significant increases in epigenetic marks associated with heterochromatin.

\section{DISCUSSION AND CONCLUSIONS}

Here, we describe the efforts to optimize a small-molecule benzimidazole pyrazole-based scaffold that was previously identified as an inhibitor of KDM4 enzymes. In doing so, we employed a strategy to alter the molecule's properties from knowledge built upon existing literature reports. This work proceeded via several modifications to the original scaffold, including the introduction of motifs capable of forming hydrogen bonds with KDM4E active-site residues (analogous to those made by $\alpha-\mathrm{KG}$ ) and introduction of motifs capable of engaging active-site regions that interact with the trimethylated $\varepsilon$-amino group of the $\mathrm{H} 3 \mathrm{~K} 9 \mathrm{me} 3$ sidechain. Surprisingly, none of these rational design features afforded gains in inhibitor potency. Despite this outcome, one prominent theme emerged from the scaffold's SAR profile (Scheme 3) that nonpolar substitutions generally enhanced potency. In particular, aromatic substitutions at the scaffold's R2 position (compound 15) resulted in the most potent design, yielding an inhibitor with greater than 10-fold improved potency relative to the original HTS hit.

Determining a mechanism of action for this inhibitor was challenging. Kinetic analyses revealed that $\mathbf{1 5}$ is noncompetitive with respect to the peptide substrate, indicating that binding sites for these two molecules do not overlap. This corroborates the finding that substituted amine modifications, unlike the methylated epsilon amino-terminus of the H3K9me3 substrate, did not enhance potency. By contrast, the uncompetitive profile with respect to $\alpha-\mathrm{KG}$ was unexpected and more difficult to interpret. On the one hand, this result indicates that $\mathbf{1 5}$ does not compete with $\alpha$-KG and, accordingly, that the binding sites do not overlap. This corroborates the finding that substitutions incorporating carboxylate sidechains, akin to $\alpha$-KG, did not enhance potency.

Ultimately, the crystal structures reported herein helped to clarify and confirm a plausible mechanism of action. Accordingly, these structures did not reveal inhibitors bound within $\mathrm{KDM} 4 \mathrm{~A} / \mathrm{D}$ active sites, where $\alpha$-KG is known to bind. Presumably, this means that inhibitor-binding sites do not overlap with $\alpha$-KG and, in agreement with kinetic analyses, that the benzimidazole pyrazole inhibitors tested are therefore not competitive with respect to this cosubstrate. Data from KDM4D crystals soaked with compound $\mathbf{1}$ were more definitive. These data indicated that a primary determinant of inhibition for the benzimidazole pyrazole-based inhibitors is 
the removal of active-site iron. Chelation of iron was expected given the scaffold's bidentate chelation center comprising two nitrogen atoms. The metal-binding site found in the inhibitor scaffold therefore likely competes with the enzyme for $\mathrm{Fe}^{2+}$ binding, thereby inhibiting its activity.

The KDM4A structures also demonstrated that the inhibitors are capable of binding to a distal site comprising a small hydrophobic binding pocket on the catalytic domain's surface. From a SAR perspective, these structures reconcile the observation that inhibitor potency increased upon introduction of nonpolar substitutions into the scaffold's R2 position and decreased upon introduction of polar substitutions. Furthermore, the observation that potency decreased upon extension of the benzylpyrazole linker or upon introducing a tolyl substitution corroborates preference of a phenyl function at position R2, likely reflecting binding to this shallow hydrophobic pocket on KDM4 enzyme surfaces. Extending from this, modifications that increase affinity for this distal binding site may enhance competition for active-site metal by incorporating an alternative binding site that would otherwise not exist. This mode of binding also demonstrates why gains in potency were not observed upon substitution of the inhibitor's benzimidazole ring or upon exchange of the benzimidazole moiety to a pyridine or to a pyridazine.

This distal binding site is structurally conserved amongst catalytic domains of all members of the KDM4 superfamily and, to date, has not yet been described as a site capable of inhibiting JmjC-KDM enzymes. Aside from the aforementioned possibility of enhancing competition for active-site $\mathrm{Fe}^{2+}$, further means by which binding to this site affects KDM4 activity remain speculative. Comparisons between the KDM4A structures presented here and those of other KDM4A catalytic domains $^{22,24,31,32}$ indicate no obvious conformational changes that propagate to the active site upon binding of the molecules described here. However, binding of the inhibitor to this site could prevent subtle molecular motion required by the enzyme for substrate turnover.

There is at least some structural evidence suggesting that the distal surface binding site is generally accessible to binding since several JmjC-KDM4 structures have been published depicting cryoprotectant molecules bound there. Relevant examples include, but are not limited to, structures of the isoforms $\mathrm{KDM}_{4} \mathrm{~A}^{33}$ (PDB ID 5F3C), KDM4C (PDB ID 5FJK), and KDM4D ${ }^{34}$ (PDB ID 5PHA) with cryoprotectant molecules forming hydrogen bonds to the homologous $\mathrm{Thr}$ residue that interacts with compounds $\mathbf{2 6}$ and 30, as observed in the KDM4A structures presented here. Given the frequency at which interactions are seen at this surface on these isoforms, it may represent an interaction hotspot, targetable, for example, by molecules derived from fragment-like compound libraries. Extending from this, the structural conservation amongst members of the KDM4 family noted above would also suggest that the benzimidazole pyrazole scaffold is not likely to be selective for any particular KDM4 isoform.

Another intriguing outcome arising from the distal binding site follows that binding to this site might contribute to the biphasic inhibition curves that we previously reported. In addition to the clear and most obvious outcome that the investigated benzimidazole pyrazole inhibitors inhibit KDM4 enzymes, at least partially (or mainly) via removal of active-site $\mathrm{Fe}^{2+}$, it is possible that binding to this surface site mediates a secondary inhibitory effect, manifesting in some doseresponse curves as biphasic inhibition. In such a model, one inhibitory phase might correspond to an event described by chelation of the active-site metal, with the second inhibitory phase corresponding to an event described by binding to the distal hydrophobic pocket.

The second goal of our optimization campaign was largely successful with regard to the activity of the KDM4 inhibitors in cellular models of prostate cancer. First, marked improvements to cellular penetrance were observed upon introduction of the benzyl substitution of compound $\mathbf{1 5}$, especially relative to the original HTS hit, compound 1, which had only marginal antiproliferative activity. This outcome facilitated the assessment of whether the cellular uptake of 15 affected KDM4dependent processes. Using the $\mathrm{KDM}^{+}$and $\mathrm{AR}^{+} \mathrm{LnCaP}$ cell line as a model of $\mathrm{PCa}$, the results presented here demonstrated that this was indeed the case. First, by the use of a reporter gene assay, intracellular 15 was demonstrated to inhibit the expression of the firefly luciferase gene under the control of an AR promoter. Since this reporter system may not directly reproduce the endogenous chromatin environment in which KDM4 enzymes are active, a second strategy was employed to directly measure AR-dependent gene expression. Accordingly, these qPCR-based analyses demonstrated that, along with the known cell-permeable KDM4 inhibitor ML324, compound $\mathbf{1 5}$ was also able to repress the AR-dependent expression of PSA. Furthermore, by directly measuring the epigenetic states of chromatin purified from $\mathrm{LnCaP}$ and DU145 cells, we demonstrated that cells treated with compound $\mathbf{1 5}$ (or with ML324) exhibited significantly lower amounts of the $\mathrm{H} 3 \mathrm{~K} 9 \mathrm{me} 3$ epigenetic mark relative to untreated cells or relative to cells treated with DMSO alone. Collectively, these experiments provide strong evidence that $\mathbf{1 5}$ inhibits KDM4 activity in cell lines known to express these targets.

Together with the results from the biochemical assays presented here, we consider that $\mathbf{1 5}$ can directly interact with KDM4 targets in living cells. However, we also acknowledge that scavenging of active-site $\mathrm{Fe}^{2+}$ may underscore a primary inhibitory role in such cells, especially since the biochemical assays involved isolated catalytic domains of these enzymes, outside the context of both their additional reader domains and outside of the greater nucleosomal environment in which they operate. As technologies for assessing cellular target engagement become more refined, they will almost certainly be of benefit to prove whether direct interactions occur. If so, we believe that the improved properties of compound $\mathbf{1 5}$ can be leveraged and further engineered to increase potency and engagement with KDM4 targets.

In conclusion, the work presented here demonstrated marked improvements to a benzimidazole pyrazole scaffold. A benzylpyrazole-substituted variant yielded the most potent KDM4 inhibitor tested, inhibiting the enzyme in part by activesite metal removal and possibly via binding to a distal binding pocket. Unlike the parent molecule, compound $\mathbf{1 5}$ is active in cellular models of PCa where it decreases both AR-dependent gene expression and the removal of $\mathrm{H} 3 \mathrm{~K} 9 \mathrm{me} 3$ epigenetic marks presumably by KDM4 inhibition. We believe these favorable properties of compound $\mathbf{1 5}$ merit its consideration either clinically as an anti-cancer agent or as a molecular probe to investigate the effects of KDM4 inhibition in relevant cellular models. 


\section{EXPERIMENTAL SECTION}

Chemicals and Reagents. Chemicals and synthesis reagents were purchased from Sigma-Aldrich (St. Louis, MO). KDM4 inhibitors ML324 and 2,4-PDCA were from Active Motif (Carlsbad, CA) and Sigma-Aldrich (St. Louis, MO), respectively. Selected pyrazole and benzimidazole scaffolds were purchased from MolPort SIA (Riga, LV). Purchased compounds were used without further purification. Enzymology reagents $(\alpha-\mathrm{KG})$, sodium ascorbate, $\mathrm{Fe}-$ $\left(\mathrm{NH}_{4}\right)_{2}\left(\mathrm{SO}_{4}\right)_{2}, \mathrm{NAD}^{+}$, and TMB (ELISA substrate) were purchased from Sigma-Aldrich (St. Louis, MO). Antibodies were purchased from Thermo Fisher Scientific (Waltham, MA) (rabbit pAb H3K9me3, Invitrogen \#49-1008), Abcam (Cambridge, UK) (mouse mAb H3K9me3, \#ab6001), BioVision (Milpitas, CA) (rabbit pAb histone H4, \#3624-100), and Cell Signaling Technology (Danvers, MA) (HRP-mouse anti-rabbit IgG, \#7074 or HRP-rabbit anti-mouse IgG, \#7076).

Small-Molecule Synthesis. Reagents and solvents were obtained from commercial suppliers and used without further purification. Organic solvents were dried using molecular sieves. ${ }^{1} \mathrm{H}$ NMR and ${ }^{13} \mathrm{C}$ NMR spectra were recorded either on an AV $300 \mathrm{MHz}$ or on an AV $600 \mathrm{MHz}$ from Bruker. Chemical shifts were recorded in parts per million (ppm). Spin multiplicities are described as s (singlet), d (doublet), $\mathrm{t}$ (triplet), $\mathrm{q}$ (quartet), or $\mathrm{m}$ (multiplet). Coupling constants $(J)$ were recorded in Hz. NMR data were analyzed with MestReNova software. Mass analyses were performed with two different spectrometers using the same column, as described below. Purity and characterization of all final compounds were established by a combination of LC-MS, LC-HRMS, and NMR analytical techniques. All compounds were found to be $>95 \%$ pure by LCMS and LC-HRMS analysis unless otherwise stated.

LCMS (method 1): Instrument: Agilent Technologies 6220 Accurate Mass TOF LC/MS linked to Agilent Technologies HPLC 1260 Series; Column: Thermo Accuore RP-MS; particle size: $2.6 \mu \mathrm{M}$, dimension: $30 \times 2.1 \mathrm{~mm}$; eluent $\mathrm{A}: \mathrm{H}_{2} \mathrm{O}$ with $0.1 \%$ formic acid; eluent $\mathrm{B}$ : $\mathrm{MeCN}$ with $0.1 \%$ formic acid; conditions: $0.00 \mathrm{~min} 95 \% \mathrm{~A}$, $0.2 \mathrm{~min} 95 \% \mathrm{~A}, 2.1 \mathrm{~min}$ to $1 \% \mathrm{~A}$ as gradient, $3 \mathrm{~min}$ as stop time, 1.3 min post time for reconstitution; flow rate: $0.8 \mathrm{~mL} / \mathrm{min}$; UVdetection: 220, 254, $300 \mathrm{~nm}$.

LCMS (method 2): Instrument: Agilent Technologies 6120 Quadrupole LC/MS linked to Agilent Technologies HPLC 1290 Infinity; Column: Thermo Accuore RP-MS; particle size: $2.6 \mu \mathrm{M}$, dimension: $30 \times 2.1 \mathrm{~mm}$; eluent $\mathrm{A}$ : $\mathrm{H}_{2} \mathrm{O}$ with $0.1 \%$ TFA; eluent $\mathrm{B}$ : MeCN with 0.1\% TFA; gradient: 0.00 min 95\% A, $0.2 \min 95 \%$ A, 1.1 $\min$ to $1 \% \mathrm{~A}$ as gradient, $2.5 \mathrm{~min}$ as stop time, $1.3 \mathrm{~min}$ post time for reconstitution; Flow rate: $0.8 \mathrm{~mL} / \mathrm{min}$; UV-detection: 220, 254, and $300 \mathrm{~nm}$. Purification of the compounds by chromatography was achieved using a CombiFlash Rf 200 UV-VIS System from Axel Semrau.

Preparative HPLC method: Instrument: Waters Prep 150 LC System ChromScope v. 1.4; Column: Machery-Nagel VP $250 \times 21$ mm Nucleodur 100-7 C18; eluent $\mathrm{A}: \mathrm{H}_{2} \mathrm{O}$ with $0.1 \%$ TFA; eluent $\mathrm{B}$ : MeCN with 0.1\% TFA; gradient: $0.00 \min 85 \%$ A, 2 min $85 \%$ A, 22 $\min 15 \%$ A, $24 \min 15 \%$ A, $26 \min 0 \%$ A, $29 \min 0 \%$ A, $32 \min 85 \%$ A; Flow rate: $30 \mathrm{~mL} / \mathrm{min}$; UV-detection: $254 \mathrm{~nm}$.

Compound 1: Methyl 2-(1-(1H-benzo[d]imidazol-2-yl)-5-hydroxy-1H-pyrazol-3-yl)acetate. $50 \mathrm{mg}$ of $(0.34 \mathrm{mmol})(1 \mathrm{H}-1,3-$ benzimidazol-2-yl)hydrazine was solubilized in $1.5 \mathrm{~mL}$ of $\mathrm{MeOH}$. 58 $\mathrm{mg}$ of $(0.34 \mathrm{mmol})$ dimethyl 3-oxopentanedioate was added, and the mixture was heated to $45^{\circ} \mathrm{C}$. After $2 \mathrm{~h}, \mathrm{MeOH}$ was removed under reduced pressure and the crude product was solubilized in $2 \mathrm{~mL}$ of $\left(\mathrm{ACN} / \mathrm{H}_{2} \mathrm{O}\right)$. The product was purified by HPLC, eluting in a gradient of $\mathrm{ACN} / \mathrm{H}_{2} \mathrm{O}$ (yield: $\left.16.2 \mathrm{mg}, 17 \%\right) .{ }^{1} \mathrm{H}$ NMR $(300 \mathrm{MHz}$, DMSO- $\left.d_{6}\right): \delta 7.51(\mathrm{dd}, J=6.0,3.2 \mathrm{~Hz}, 2 \mathrm{H}), 7.16(\mathrm{dd}, J=6.0,3.2 \mathrm{~Hz}$, $2 \mathrm{H}), 5.24(\mathrm{~s}, 1 \mathrm{H}), 3.64(\mathrm{~s}, 3 \mathrm{H})$, and $3.59(\mathrm{~s}, 2 \mathrm{H}) .{ }^{13} \mathrm{C}$ NMR $(75$ $\left.\mathrm{MHz}, \mathrm{DMOS}-d_{6}\right): \delta 170.4,150.1,145.4,135.8,122.3,114.5,52.1$, and 34.9. LCMS (method 1): $R_{t}=1.051 \mathrm{~min}$; HRMS (ESIpos): $m / z$ [M $+\mathrm{Na}]^{+}$calcd for $\mathrm{C}_{13} \mathrm{H}_{12} \mathrm{~N}_{4} \mathrm{O}_{3}, 295.0802$; found, 295.0799.

Compound 2: 2-(1-(1H-Benzo[d]imidazol-2-yl)-5-hydroxy-1Hpyrazol-3-yl)acetic Acid. $16 \mathrm{mg}$ of $(0.33 \mathrm{mmol}) 1$ was dissolved in $1 \mathrm{~mL}$ of $\mathrm{THF}$, and $1 \mathrm{~mL}$ of $1 \mathrm{M} \mathrm{LiOH}$ aqueous solution was added.
After saponification, the mixture was acidified with $2 \mathrm{M} \mathrm{HCl}$ to $\mathrm{pH}<$ 3 and the product, precipitated as a white solid, was filtered off, and washed with water and with $\mathrm{Et}_{2} \mathrm{O}$ (yield: $15 \mathrm{mg}$, quant). ${ }^{1} \mathrm{H}$ NMR $\left(300 \mathrm{MHz}, \mathrm{DMSO}-d_{6}\right): \delta 7.49-7.37(\mathrm{~m}, 2 \mathrm{H}), 7.05-6.95(\mathrm{~m}, 2 \mathrm{H})$, $4.59(\mathrm{~s}, 1 \mathrm{H})$, and $3.17(\mathrm{~s}, 2 \mathrm{H}) .{ }^{13} \mathrm{C}$ NMR $\left(75 \mathrm{MHz}, \mathrm{DMSO}-d_{6}\right): \delta$ $175.0,165.8,153.5,149.1,120.7,83.4$, and $48.9, \mathrm{CH}_{2} \mathrm{CO}_{2} \mathrm{H}$ overlay DMSO peak. LCMS (method 1): $R_{t}=0.883$ min; HRMS (ESIpos): $m / z[\mathrm{M}+\mathrm{Na}]^{+}$calcd for $\mathrm{C}_{12} \mathrm{H}_{10} \mathrm{~N}_{4} \mathrm{O}_{3}, 259.0826$; found, 259.0828 .

Compound 3: Methyl 3-(1-(1H-benzo[d]imidazol-2-yl)-5-hydroxy-3-methyl-1H-pyrazol-4-yl)propanoate. $22 \mathrm{mg}$ of $(0.15$ mmol) (1H-1,3-benzimidazol-2-yl)hydrazine was solubilized in 0.5 $\mathrm{mL}$ of $\mathrm{MeOH} .30 \mathrm{mg}$ of $(0.15 \mathrm{mmol})$ dimethyl 2-acetylglutarate was added, and the mixture was heated to $45^{\circ} \mathrm{C}$. After $2 \mathrm{~h}, \mathrm{MeOH}$ was removed under reduced pressure, $1 \mathrm{~mL}$ of $\mathrm{Et}_{2} \mathrm{O}$ was added, and the product, precipitated as a white solid, was filtered off and washed with $\mathrm{Et}_{2} \mathrm{O}$ (yield: $\left.34 \mathrm{mg}, 76 \%\right) .{ }^{1} \mathrm{H}$ NMR $(300 \mathrm{MHz}$, chloroform- $d$ ): $\delta$ 7.44-7.37 (m, 2H), 7.26-7.21 (m, 2H), $3.70(\mathrm{~s}, 3 \mathrm{H}), 2.73-2.70(\mathrm{~m}$, $4 \mathrm{H})$, and $2.24(\mathrm{~s}, 3 \mathrm{H})$. LCMS (method 2): $R_{t}=0.948 \mathrm{~min} ; \mathrm{MS}$ (ESIpos): $m / z[\mathrm{M}+\mathrm{H}]^{+} 301.2$.

Compound 4: Ethyl 3-(1-(1H-benzo[d]imidazol-2-yl)-5-hydroxy4-methyl-1H-pyrazol-3-yl)propanoate. $20 \mathrm{mg}$ of $(0.14 \mathrm{mmol})(1 \mathrm{H}$ 1,3-benzimidazol-2-yl)hydrazine was solubilized in $1 \mathrm{~mL}$ of EtOH. 30 $\mathrm{mg}$ of $(0.14 \mathrm{mmol})$ diethyl-2-methyl-3-oxoadipate was added, and the mixture was heated to $75^{\circ} \mathrm{C}$. After $2 \mathrm{~h}$, EtOH was removed under reduced pressure, $1 \mathrm{~mL}$ of $\mathrm{Et}_{2} \mathrm{O}$ was added, and the product, precipitated as a white solid, was filtered off and washed with $\mathrm{Et}_{2} \mathrm{O}$ (yield: $20 \mathrm{mg}, 51 \%) .{ }^{1} \mathrm{H}$ NMR $(300 \mathrm{MHz}$, chloroform- $d$ ): $\delta 7.60-$ $7.52(\mathrm{~m}, 2 \mathrm{H}), 7.36-7.30(\mathrm{~m}, 2 \mathrm{H}), 4.15(\mathrm{q}, J=7.2 \mathrm{~Hz}, 2 \mathrm{H}), 2.92(\mathrm{t}, J$ $=7.2 \mathrm{~Hz}, 2 \mathrm{H}), 2.72(\mathrm{t}, J=7.2 \mathrm{~Hz}, 2 \mathrm{H}), 1.95(\mathrm{~s}, 3 \mathrm{H})$, and $1.25(\mathrm{t}, J=$ $7.1 \mathrm{~Hz}, 3 \mathrm{H})$. LCMS (method 2): $R_{t}=1.029 \mathrm{~min} ;$ MS $($ ESIpos): $\mathrm{m} / z$ $[\mathrm{M}+\mathrm{H}]^{+}$315.2.

Compound 5: 3-(1-(1H-Benzo[d]imidazol-2-yl)-5-hydroxy-3methyl-1H-pyrazol-4-yl)propanoic Acid. $20 \mathrm{mg}$ of $(0.07 \mathrm{mmol}) 3$ was dissolved in $1 \mathrm{~mL}$ of THF, and $1 \mathrm{~mL}$ of $1 \mathrm{M} \mathrm{LiOH}$ aqueous solution was added. After saponification, the mixture was acidified with $2 \mathrm{M} \mathrm{HCl}$ to make the $\mathrm{pH}=3$, and the product, precipitated as a white solid, was filtered off and washed with water and with $\mathrm{Et}_{2} \mathrm{O}$ (yield: $19 \mathrm{mg}$, quant). ${ }^{1} \mathrm{H}$ NMR (300 MHz, DMSO- $\left.d_{6}\right): \delta 7.62-7.55$ $(\mathrm{m}, 2 \mathrm{H}), 7.30-7.24(\mathrm{~m}, 2 \mathrm{H}), 2.56-2.44(\mathrm{~m}, 4 \mathrm{H}$, overlay DMSO), and $2.22(\mathrm{~s}, 3 \mathrm{H})$. LCMS (method 2): $R_{t}=0.864 \mathrm{~min}$; MS (ESIpos): $\mathrm{m} / z[\mathrm{M}+\mathrm{H}]^{+}$281.1.

Compound 6: 3-(1-(1H-benzo[d]imidazol-2-yl)-5-hydroxy-4methyl-1H-pyrazol-3-yl)propanoic Acid. $10 \mathrm{mg}$ of $(0.035 \mathrm{mmol}) 4$ was dissolved in $1 \mathrm{~mL}$ of THF and $1 \mathrm{~mL}$ of $1 \mathrm{M} \mathrm{LiOH}$ aqueous solution was added. After saponification, the mixture was acidified with $2 \mathrm{M} \mathrm{HCl}$ to $\mathrm{pH}<3$, and the product, precipitated as a white solid, was filtered off and washed with water and with $\mathrm{Et}_{2} \mathrm{O}$ (yield: 9 $\mathrm{mg}$, quant). ${ }^{1} \mathrm{H}$ NMR $\left(300 \mathrm{MHz}\right.$, DMSO- $\left.d_{6}\right): \delta 7.56-7.48(\mathrm{~m}, 2 \mathrm{H})$, $7.19-7.13(\mathrm{~m}, 2 \mathrm{H}), 2.77(\mathrm{t}, J=7.9 \mathrm{~Hz}, 2 \mathrm{H}), 2.62(\mathrm{t}, J=7.4 \mathrm{~Hz}, 2 \mathrm{H})$, and $1.80(\mathrm{~s}, 3 \mathrm{H})$. LCMS (method 2$): R_{t}=0.88 \mathrm{~min}$; MS (ESIpos): $m / z[\mathrm{M}+\mathrm{H}]^{+}$287.2.

Compound 7: 3-(1-(1H-Benzo[d]imidazol-2-yl)-5-hydroxy-3methyl-1H-pyrazol-4-yl)-N-methylpropanamide. $114 \mathrm{mg}$ of (0.4 mmol) 5 was dissolved in $1 \mathrm{~mL}$ of DMF, and $54.2 \mathrm{mg}$ of $(0.4 \mathrm{mmol})$ HOBt, $76.3 \mathrm{mg}$ of $(0.4 \mathrm{mmol}) \mathrm{EDC}$, and $138 \mu \mathrm{L}(0.8 \mathrm{mmol})$ of DIPEA were added to the reaction mixture. $34 \mu \mathrm{L}$ of $(0.4 \mathrm{mmol})$ methylamine was added, and the mixture was stirred for $16 \mathrm{~h}$. After completion of the amidation, the mixture was quenched with $\mathrm{H}_{2} \mathrm{O}$ and extracted 3 times with DCM. The combined organic phases were removed under reduced pressure, and the raw product was purified by HPLC, eluting in a gradient of $\mathrm{ACN} / \mathrm{H}_{2} \mathrm{O}$ (yield: $67 \mathrm{mg}, 56 \%$ ). ${ }^{1} \mathrm{H}$ NMR $\left(300 \mathrm{MHz}\right.$, DMSO- $\left.d_{6}\right): \delta 7.94-7.85(\mathrm{~m}, 1 \mathrm{H}), 7.59-7.54(\mathrm{~m}$, $2 \mathrm{H}), 7.26-7.20(\mathrm{~m}, 2 \mathrm{H}), 2.57(\mathrm{~s}, 3 \mathrm{H}), 2.52-2.46(\mathrm{~m}, 2 \mathrm{H}$, overlay DMSO peak), $2.30(\mathrm{t}, J=7.4 \mathrm{~Hz}, 2 \mathrm{H})$, and $2.18(\mathrm{~s}, 3 \mathrm{H}) .{ }^{13} \mathrm{C}$ NMR $\left(75 \mathrm{MHz}, \mathrm{DMSO}-d_{6}\right): \delta 172.6,158.9,152.3,143.2,134.8,122.9$, $114.5,102.4,35.0,25.9,18.0$, and 11.9. LCMS (method 1): $R_{t}=1.145$ min; HRMS (ESIpos): $m / z[\mathrm{M}+\mathrm{H}]^{+}$calcd for $\mathrm{C}_{15} \mathrm{H}_{17} \mathrm{~N}_{5} \mathrm{O}_{2}$, 300.1455; found, 300.1455 .

Compound 8: 3-(1-(1H-Benzo[d]imidazol-2-yl)-5-hydroxy-3methyl-1H-pyrazol-4-yl)-N,N-dimethylpropanamide. $114 \mathrm{mg}$ of 
(0.4 mmol) 6 was dissolved in $1 \mathrm{~mL}$ of DMF, and $54.2 \mathrm{mg}$ of $(0.4$ $\mathrm{mmol}) \mathrm{HOBt}, 76.3 \mathrm{mg}$ of $(0.4 \mathrm{mmol}) \mathrm{EDC}$, and $138 \mu \mathrm{L}(0.8 \mathrm{mmol})$ of DIPEA were added to the reaction mixture. $200 \mu \mathrm{L}$ of $(0.4 \mathrm{mmol} 2$ $\mathrm{M}$ in THF) dimethylamine was added, and the mixture was stirred for $16 \mathrm{~h}$. After completion of the amidation, the mixture was quenched with $\mathrm{H}_{2} \mathrm{O}$ and extracted 3 times with DCM. The combined organic phases were removed under reduced pressure, and the raw product was purified by HPLC, eluting in a gradient of $\mathrm{ACN} / \mathrm{H}_{2} \mathrm{O}$ (yield: 58 $\mathrm{mg}, 47 \%) .{ }^{1} \mathrm{H}$ NMR (300 MHz, DMSO- $\left.d_{6}\right): \delta 7.57-7.50(\mathrm{~m}, 2 \mathrm{H})$, 7.23-7.17 (m, 2H), $2.95(\mathrm{~s}, 3 \mathrm{H}), 2.82(\mathrm{~s}, 3 \mathrm{H}), 2.57-2.45(\mathrm{~m}, 4 \mathrm{H}$, overlay DMSO peak), and $2.20(\mathrm{~s}, 3 \mathrm{H}) .{ }^{13} \mathrm{C}$ NMR $(75 \mathrm{MHz}$, DMSO$\left.d_{6}\right): \delta 172.0,158.9,151.6,143.4,135.5,122.6,114.6,102.5,37.0,35.2$, 32.1, 17.7, and 11.7. LCMS (method 1): $R_{t}=1.248 \mathrm{~min}$; HRMS (ESIpos): $m / z[\mathrm{M}+\mathrm{H}]^{+}$calcd for $\mathrm{C}_{16} \mathrm{H}_{19} \mathrm{~N}_{5} \mathrm{O}_{2}, 314.1612$; found, 314.1612.

Compound 9: 1-(1H-Benzo[d]imidazol-2-yl)-3-methyl-4-(3(methylamino)propyl)-1H-pyrazol-5-ol. $30 \mathrm{mg}$ of $(0.1 \mathrm{mmol}) 7$ was dissolved in $1 \mathrm{~mL}$ of DCM/THF $1: 1$, and $24 \mu \mathrm{L}$ of borane dimethylsulfide complex $(\delta=0.801 \mathrm{~g} / \mathrm{mL}, 0.25 \mathrm{mmol})$ was added. The reaction was quenched with $\mathrm{H}_{2} \mathrm{O}$, and $\mathrm{NaOH}$ was added to make the $\mathrm{pH}=10$. The aqueous phase was extracted 3 times with $\mathrm{Et}_{2} \mathrm{O}$. The combined organic phases were removed under reduced pressure, and the raw product was purified by HPLC, eluting in a gradient of $\mathrm{ACN} / \mathrm{H}_{2} \mathrm{O}$ (yield: $8 \mathrm{mg}, 28 \%$ ). ${ }^{1} \mathrm{H}$ NMR (300 MHz, DMSO- $d_{6}$ ): $\delta$ $8.84(\mathrm{~s}, 2 \mathrm{H}), 7.57-7.48(\mathrm{~m}, 2 \mathrm{H}), 7.19-7.12(\mathrm{~m}, 2 \mathrm{H}), 2.96-2.85(\mathrm{~m}$, $2 \mathrm{H}), 2.52-2.48(\mathrm{~m}, 2 \mathrm{H}), 2.31(\mathrm{t}, J=7.1 \mathrm{~Hz}, 2 \mathrm{H}), 2.19(\mathrm{~s}, 3 \mathrm{H})$, and $1.84-1.74(\mathrm{~m}, 2 \mathrm{H})$. LCMS (method 2): $R_{t}=0.44 \mathrm{~min}$; MS (ESIpos): $m / z[\mathrm{M}+\mathrm{H}]^{+} 286.2$.

Compound 10: 1-(1H-Benzo[d]imidazol-2-yl)-4-(3(dimethylamino)propyl)-3-methyl-1H-pyrazol-5-ol. $30 \mathrm{mg}$ of (0.1 mmol) 8 was dissolved in $1 \mathrm{~mL}$ of DCM/THF 1:1, and $24 \mu \mathrm{L}$ of borane dimethylsulfide complex $(\delta=0.801 \mathrm{~g} / \mathrm{mL}, 0.25 \mathrm{mmol})$ was added. The reaction was quenched with $\mathrm{H}_{2} \mathrm{O}$, and $\mathrm{NaOH}$ was added to make the $\mathrm{pH}=10$. The aqueous phase was extracted 3 times with $\mathrm{Et}_{2} \mathrm{O}$. The combined organic phases were removed under reduced pressure, and the raw product was purified by HPLC, eluting in a gradient of $\mathrm{ACN} / \mathrm{H}_{2} \mathrm{O}$ (yield: $\left.7 \mathrm{mg}, 24 \%\right) .{ }^{1} \mathrm{H}$ NMR $(300 \mathrm{MHz}$, DMSO- $\left.d_{6}\right): \delta 7.55-7.48(\mathrm{~m}, 2 \mathrm{H}), 7.17-7.12(\mathrm{~m}, 2 \mathrm{H}), 2.74-2.68$ $(\mathrm{m}, 2 \mathrm{H}), 2.46(\mathrm{~s}, 6 \mathrm{H}), 2.24(\mathrm{t}, J=7.3 \mathrm{~Hz}, 2 \mathrm{H}), 2.18(\mathrm{~s}, 3 \mathrm{H})$, and 1.91-1.80 (m, 2H). LCMS (method 2): $R_{t}=1.006 \mathrm{~min} ; \mathrm{MS}$ (ESIpos): $m / z[\mathrm{M}+\mathrm{H}]^{+} 300.3$.

Compound 11: 1-(1H-Benzo[d]imidazol-2-yl)-3-methyl-1H-pyrazol-5-ol. $19 \mathrm{mg}$ of $(0.13 \mathrm{mmol})$ (1H-1,3-benzimidazol-2-yl)hydrazine was solubilized in $0.5 \mathrm{~mL}$ of $\mathrm{MeOH} .20 \mathrm{mg}$ of $(0.13$ $\mathrm{mmol}$ ) methyl acetoacetate was added, and the mixture was heated to $45{ }^{\circ} \mathrm{C}$. After cooling to RT, a white solid precipitated as a side product. The mixture was centrifuged and the filtrate contained the pure product. The white solid was washed with $\mathrm{MeOH}$ several times, followed by centrifugation. The combined organic $\mathrm{MeOH}$ phases were removed under reduced pressure, and the product was obtained as a white solid (yield: $19 \mathrm{mg}, 67 \%) .{ }^{1} \mathrm{H}$ NMR (300 MHz, DMSO$\left.d_{6}\right): \delta 7.55-7.49(\mathrm{~m}, 2 \mathrm{H}), 7.18-7.13(\mathrm{~m}, 2 \mathrm{H}), 5.23(\mathrm{~s}, 1 \mathrm{H})$, and 2.19 $(\mathrm{s}, 3 \mathrm{H}) .{ }^{13} \mathrm{C}$ NMR (75 MHz, DMSO- $\left.d_{6}\right): \delta 161.4,153.0,144.2$, 136.4, 122.2, 114.7, 90.2, and 13.3. LCMS (method 1): $R_{t}=0.798$ min; HRMS (ESIpos): $\mathrm{m} / z[\mathrm{M}+\mathrm{H}]^{+}$calcd for $\mathrm{C}_{11} \mathrm{H}_{10} \mathrm{~N}_{4} \mathrm{O}$, 215.0927; found, 215.0927.

Compound 12: 4-Allyl-1-(1H-benzo[d]imidazol-2-yl)-3-methyl$1 \mathrm{H}$-pyrazol-5-ol. $43.5 \mathrm{mg}$ of $(0.29 \mathrm{mmol})(1 \mathrm{H}$-1,3-benzimidazol-2yl)hydrazine was solubilized in $4 \mathrm{~mL}$ of EtOH. $50 \mathrm{mg}$ of $(0.29 \mathrm{mmol})$ ethyl-2-acetylpent-4-enoate was added, and the mixture was heated to $80^{\circ} \mathrm{C}$. After $2 \mathrm{~h}, \mathrm{EtOH}$ was removed under reduced pressure, and the crude product was solubilized in $2 \mathrm{~mL}$ of $\left(\mathrm{ACN} / \mathrm{H}_{2} \mathrm{O}\right)$. The product was purified by HPLC, eluting in a gradient of $\mathrm{ACN} / \mathrm{H}_{2} \mathrm{O}$ (yield: 14 $\mathrm{mg}, 19 \%) .{ }^{1} \mathrm{H}$ NMR (300 MHz, chloroform- $d$ ): $\delta 9.52(\mathrm{~s}, 2 \mathrm{H}), 7.69-$ $7.59(\mathrm{~m}, 2 \mathrm{H}), 7.47-7.39(\mathrm{~m}, 2 \mathrm{H}), 5.95-5.80(\mathrm{~m}, 1 \mathrm{H}), 5.11(\mathrm{dd}, J=$ $1.9 \mathrm{~Hz}, 1 \mathrm{H}), 5.07(\mathrm{dd}, J=4.1,1.9 \mathrm{~Hz}, 1 \mathrm{H}), 3.12(\mathrm{dt}, J=6.1,1.8 \mathrm{~Hz}$, $2 \mathrm{H})$, and $2.32(\mathrm{~s}, 3 \mathrm{H}) .{ }^{13} \mathrm{C}$ NMR $(75 \mathrm{MHz}$, chloroform- $d): \delta 164.6$, $164.2,156.4,141.5,134.4,115.6,102.4,25.5$, and 11.7. LCMS (method 1): $R_{t}=1.223$ min; HRMS (ESIpos): $m / z[\mathrm{M}+\mathrm{H}]^{+}$calcd for $\mathrm{C}_{14} \mathrm{H}_{14} \mathrm{~N}_{4} \mathrm{O}$, 255.1240; found, 255.1246 .
Compound 13: 1-(1H-Benzo[d]imidazol-2-yl)-3-methyl-4-propyl-1H-pyrazol-5-ol. $12 \mathrm{mg}$ of $(0.05 \mathrm{mmol}) 12$ was dissolved in $1 \mathrm{~mL}$ of $\mathrm{MeOH}$, and $\mathrm{Pd} / \mathrm{C}$ was added. The reaction vessel was flushed with hydrogen and stirred for $1 \mathrm{~h}$ at RT. Pd/C was filtered off with celite, and the solvent was removed under reduced pressure. The product was purified by HPLC, eluting in a gradient of $\mathrm{ACN} / \mathrm{H}_{2} \mathrm{O}$ (yield: 10.9 $\mathrm{mg}, 90 \%) .{ }^{1} \mathrm{H}$ NMR $\left(300 \mathrm{MHz}\right.$, methanol- $\left.d_{4}\right): \delta 7.68-7.60(\mathrm{~m}, 2 \mathrm{H})$, 7.45-7.36 (m, 2H), 2.41-2.32 (m, 2H), 2.32-2.25 (m, 3H), 1.64$1.52(\mathrm{~m}, 2 \mathrm{H})$, and $1.03-0.93(\mathrm{~m}, 3 \mathrm{H}) .{ }^{13} \mathrm{C}$ NMR $(75 \mathrm{MHz}$, methanol- $\left.d_{4}\right): \delta 159.0,155.3,141.9,131.7,124.0,113.2,104.3,23.0$, 22.2, 12.6, and 10.9. LCMS (method 1): $R_{t}=1.306 \mathrm{~min}$; HRMS (ESIpos): $m / z[\mathrm{M}+\mathrm{H}]^{+}$calcd for $\mathrm{C}_{14} \mathrm{H}_{16} \mathrm{~N}_{4} \mathrm{O}, 257.1397$; found, 257.1396.

Compound 14: 1-(1H-Benzo[d]imidazol-2-yl)-3-methyl-4-(prop2-yn-1-yl)-1H-pyrazol-5-ol. $81 \mathrm{mg}$ of $(0.55 \mathrm{mmol})(1 \mathrm{H}-1,3-$ benzimidazol-2-yl)hydrazine was solubilized in $2 \mathrm{~mL}$ of EtOH. 92 $\mathrm{mg}$ of $(0.55 \mathrm{mmol})$ ethyl 2 -acetylpent-4-ynoate was added, and the mixture was heated to $75{ }^{\circ} \mathrm{C}$. After $2 \mathrm{~h}$, EtOH was removed under reduced pressure, and the raw product was purified by HPLC, eluting in a gradient of $\mathrm{ACN} / \mathrm{H}_{2} \mathrm{O}$ (yield: $\left.54 \mathrm{mg}, 39 \%\right) .{ }^{1} \mathrm{H} \mathrm{NMR}(300 \mathrm{MHz}$, DMSO- $\left.d_{6}\right): \delta 7.55(\mathrm{dd}, J=5.8,3.1 \mathrm{~Hz}, 2 \mathrm{H}), 7.22(\mathrm{dd}, J=5.8,3.1 \mathrm{~Hz}$, $2 \mathrm{H}), 3.25-3.18(\mathrm{~m}, 2 \mathrm{H}), 2.84(\mathrm{t}, J=2.9 \mathrm{~Hz}, 1 \mathrm{H})$, and $2.25(\mathrm{~s}, 3 \mathrm{H})$. ${ }^{13} \mathrm{C}$ NMR $\left(75 \mathrm{MHz}\right.$, DMSO-d $\left.d_{6}\right): \delta 159.4,151.8,143.4,135.3,122.7$, 114.6, 97.6, 82.3, 70.9, 11.9, and 11.2. LCMS (method 1): $R_{t}=1.179$ min; HRMS (ESIpos): $m / z[\mathrm{M}+\mathrm{H}]^{+}$calcd for $\mathrm{C}_{14} \mathrm{H}_{13} \mathrm{~N}_{4} \mathrm{O}$, 253.1084; found, 253.1082.

Compound 15: 1-(1H-Benzo[d]imidazol-2-yl)-3-methyl-4-phenyl-1H-pyrazol-5-ol. $1.05 \mathrm{~g}(0.01 \mathrm{~mol})$ of $(1 \mathrm{H}-1,3$-benzimidazol-2$\mathrm{yl}$ )hydrazine was solubilized in $40 \mathrm{~mL}$ of EtOH. $1.46 \mathrm{~g}(0.01 \mathrm{~mol})$ of ethyl 3-oxo-2-phenylbutanoate was added, and the reaction mixture was stirred at $80{ }^{\circ} \mathrm{C}$ for $16 \mathrm{~h}$. EtOH was evaporated, and the crude product was purified by chromatography on silica gel, eluting with a gradient of DCM/MeOH (yield: $640 \mathrm{mg} 31 \%) .{ }^{1} \mathrm{H}$ NMR $(300 \mathrm{MHz}$, DMSO- $\left.d_{6}\right): \delta 7.66(\mathrm{~d}, J=7.6 \mathrm{~Hz}, 2 \mathrm{H}), 7.60-7.53(\mathrm{~m}, 2 \mathrm{H}), 7.41-$ $7.33(\mathrm{~m}, 2 \mathrm{H}), 7.23(\mathrm{dd},=6.0,3.2 \mathrm{~Hz}, 2 \mathrm{H}), 7.19-7.13(\mathrm{~m}, 1 \mathrm{H})$, and $2.40(\mathrm{~s}, 3 \mathrm{H}) .{ }^{13} \mathrm{C}$ NMR $\left(75 \mathrm{MHz}\right.$, DMSO- $\left.d_{6}\right): \delta 160.9,151.1,143.5$, 134.6, 133.4, 128.5, 127.0, 125.1, 122.8, 114.4, 100.6, and 14.2. LCMS (method 1): $R_{t}=1.305$ min; HRMS (ESIpos): $m / z[\mathrm{M}+\mathrm{H}]^{+}$calcd for $\mathrm{C}_{17} \mathrm{H}_{14} \mathrm{~N}_{4} \mathrm{O}$, 291.1240; found, 291.1238.

Compound 16: 1-(1H-Benzo[d]imidazol-2-yl)-4-benzyl-3-methyl-1H-pyrazol-5-ol. $33.6 \mathrm{mg}$ of (0.23 mmol) (1H-1,3-benzimidazol-2yl)hydrazine was solubilized in $4 \mathrm{~mL}$ of EtOH. After addition of 50 $\mathrm{mg}$ of $(0.23 \mathrm{mmol})$ ethyl-2-benzylacetoacetate, the reaction mixture was stirred at $80{ }^{\circ} \mathrm{C}$ for $2 \mathrm{~h}$. EtOH was evaporated, solubilized in ACN $/ \mathrm{H}_{2} \mathrm{O}$, and purified by HPLC, eluting in a gradient of ACN/ $\mathrm{H}_{2} \mathrm{O}$ (yield: $\left.29 \mathrm{mg}, 42 \%\right) .{ }^{1} \mathrm{H}$ NMR (300 MHz, chloroform- $d$ ): $\delta 9.29$ (s, 2H), 7.61-7.53 (m, 2H), 7.42-7.34 (m, 2H), 7.30-7.17 (m, 5H), $3.70(\mathrm{~s}, 2 \mathrm{H})$, and $2.28(\mathrm{~s}, 3 \mathrm{H}) .{ }^{13} \mathrm{C}$ NMR $(75 \mathrm{MHz}$, chloroform- $d): \delta$ $164.7,156.1,141.4,138.9,128.5,127.9,126.4,125.1,104.0,27.4$, and 11.9. LCMS (method 1): $R_{t}=1.329$ min; HRMS (ESIpos): $\mathrm{m} / z[\mathrm{M}$ $+\mathrm{H}]^{+}$calcd for $\mathrm{C}_{18} \mathrm{H}_{16} \mathrm{~N}_{4} \mathrm{O}$, 305.1397; found, 305.1383.

Compound 17: 1-(1H-Benzo[d]imidazol-2-yl)-3-methyl-4- $(p-$ tolyl)-1 H-pyrazol-5-ol. $40 \mathrm{mg}$ of $(0.27 \mathrm{mmol})(1 \mathrm{H}-1,3$-benzimidazol-2-yl)hydrazine was solubilized in $4 \mathrm{~mL}$ of EtOH. $60 \mathrm{mg}$ of $(0.27$ $\mathrm{mmol}$ ) ethyl 3-oxo-2-p-tolylbutanoate was added, and the reaction mixture was stirred at $80{ }^{\circ} \mathrm{C}$ for $2 \mathrm{~h}$. EtOH was evaporated, and the crude product was homogenized in $1 \mathrm{~mL}$ of $\mathrm{MeOH}$. Upon addition of $\mathrm{H}_{2} \mathrm{O}$, the product precipitated and was filtered off and washed with ether (yield: $39 \mathrm{mg}, 47 \%) .{ }^{1} \mathrm{H}$ NMR (300 MHz, DMSO- $\left.d_{6}\right): \delta 7.59-$ $7.50(\mathrm{~m}, 4 \mathrm{H}), 7.22-7.12(\mathrm{~m}, 4 \mathrm{H}), 2.36(\mathrm{~s}, 3 \mathrm{H})$, and $2.29(\mathrm{~s}, 3 \mathrm{H}) .{ }^{13} \mathrm{C}$ NMR $\left(75 \mathrm{MHz}, \mathrm{DMSO}-d_{6}\right): \delta 161.0,150.3,144.6,135.6,133.8$, $130.8,129.1,126.9,122.3,114.4,100.4,21.1$, and 14.4. LCMS (method 1): $R_{t}=1.365$ min; HRMS (ESIpos): $m / z[\mathrm{M}+\mathrm{H}]^{+}$calcd for $\mathrm{C}_{18} \mathrm{H}_{16} \mathrm{~N}_{4} \mathrm{O}$, 305.1397; found, 305.1398.

Compound 18: 1-(1H-Benzo[d]imidazol-2-yl)-3-ethyl-4-phenyl1H-pyrazol-5-ol in Three Steps. Synthesis of methyl 3-hydroxy-2phenylpentanoate: $187 \mu \mathrm{L}$ of $(1.33 \mathrm{mmol})$ methyl phenylacetate was dissolved in $5 \mathrm{~mL}$ of THF. The reaction mixture was cooled to -78 ${ }^{\circ} \mathrm{C}$, and LDA was added, followed by the addition of $96 \mu \mathrm{L}$ of $(1.33$ $\mathrm{mmol}$ ) propionaldehyde solubilized in $3 \mathrm{~mL}$ of THF. The mixture 
was kept for $1 \mathrm{~h}$ at $-78{ }^{\circ} \mathrm{C}$ and then allowed to warm to $0{ }^{\circ} \mathrm{C}$ and quenched with an $\mathrm{NH}_{4} \mathrm{Cl}$ solution. The aqueous phase was washed 3 times with EtOAc and dried over $\mathrm{Mg}_{2} \mathrm{SO}_{4}$. The crude product was purified by chromatography on silica gel, eluting with a gradient of hexane/EtOAc. Fractions containing the product were combined, and the solvent was evaporated under reduced pressure (yield: $46.5 \mathrm{mg}$, 17\%). ${ }^{1} \mathrm{H}$ NMR (300 MHz, chloroform- $d$ ): $\delta$ 7.37-7.26 (m, 5H), $4.12(\mathrm{td}, J=8.7,3.4 \mathrm{~Hz}, 1 \mathrm{H}), 3.69(\mathrm{~s}, 3 \mathrm{H}), 3.61(\mathrm{~d}, J=9.2 \mathrm{~Hz}, 1 \mathrm{H})$, $1.33,1.22(\mathrm{~m}, 2 \mathrm{H})$, and $0.93\left(\mathrm{t}, J=7.4 \mathrm{~Hz},{ }^{3} \mathrm{H}\right) .{ }^{13} \mathrm{C} \mathrm{NMR}(75 \mathrm{MHz}$, chloroform- $d$ ): $\delta$ 174.1, 136.1, 128.7, 128.3, 127.6, 74.4, 58.1, 52.1, 26.6, and 9.6. LCMS (method 1): $R_{t}=1.328$ min; HRMS (ESIpos): $m / z[\mathrm{M}+\mathrm{Na}]^{+}$calcd for $\mathrm{C}_{12} \mathrm{H}_{16} \mathrm{O}_{3}, 231.0992$; found, 231.0986.

To $2 \mathrm{~mL}$ of DCM solution at $-78{ }^{\circ} \mathrm{C}, 63 \mu \mathrm{L}$ of $(0.89 \mathrm{mmol})$ DMSO and $70 \mu \mathrm{L}$ of $(0.67 \mathrm{mmol})$ oxalyl chloride were added, and the mixture was stirred for $10 \mathrm{~min}$. Afterward, $46.5 \mathrm{mg}$ of $(0.22$ mmol) of methyl 3-hydroxy-2-phenylpentanoate, together with 370 $\mu \mathrm{L}$ of $(2.9 \mathrm{mmol})$ of trimethylamine in $900 \mu \mathrm{L}$ of DCM were added dropwise at $-78{ }^{\circ} \mathrm{C}$. After $2 \mathrm{~h}$, the mixture was quenched with $2 \mathrm{M}$ $\mathrm{HCl}$, and the aqueous phase was extracted 3 times with DCM. The combined organic phases were dried with $\mathrm{Na}_{2} \mathrm{SO}_{4}, \mathrm{DCM}$ was removed under reduced pressure, and the raw product was obtained as a yellowish oil $(70 \mathrm{mg})$. It was used as the raw product in the last step of the synthesis. $33 \mathrm{mg}$ of $(0.22 \mathrm{mmol})(1 \mathrm{H}$-1,3-benzimidazol-2yl)hydrazine was solubilized in $1 \mathrm{~mL}$ of EtOH. After the addition of raw $70 \mathrm{mg}$ of $(0.55 \mathrm{mmol})$ methyl 3-oxo-2-phenylpentanoate, the reaction mixture was stirred at $75^{\circ} \mathrm{C}$ for $2 \mathrm{~h}$. EtOH was evaporated, and the crude product was solubilized in $\mathrm{ACN} / \mathrm{H}_{2} \mathrm{O}$ and purified by HPLC, eluting in a gradient of $\mathrm{ACN} / \mathrm{H}_{2} \mathrm{O}$ (yield: $8 \mathrm{mg}, 12 \%$ for two steps). ${ }^{1} \mathrm{H}$ NMR (300 MHz, chloroform- $d$ ): $\delta 7.53(\mathrm{~d}, J=7.2 \mathrm{~Hz}$, $3 \mathrm{H}), 7.49-7.41(\mathrm{~m}, 3 \mathrm{H}), 7.39-7.31(\mathrm{~m}, 3 \mathrm{H}), 2.87(\mathrm{q}, J=7.6 \mathrm{~Hz}$, $2 \mathrm{H})$, and $1.33(\mathrm{t}, J=7.6 \mathrm{~Hz}, 3 \mathrm{H}) .{ }^{13} \mathrm{C}$ NMR $(75 \mathrm{MHz}$, chloroformd): $\delta 164.4,163.0,160.0,141.7,129.7,128.7,128.6,127.3,125.0$, 105.3, 20.3, and 12.4. LCMS (method 1): $R_{t}=1.376 \mathrm{~min}$; HRMS (ESIpos): $m / z[\mathrm{M}+\mathrm{H}]^{+}$calcd for $\mathrm{C}_{18} \mathrm{H}_{16} \mathrm{~N}_{4} \mathrm{O}, 305.1397$; found, 305.1399.

Compound 19: 1-(1H-Benzo[d]imidazol-2-yl)-3-butyl-4-phenyl1H-pyrazol-5-ol in Three Steps. Synthesis of methyl 3-hydroxy-2phenylheptanoate: $187 \mu \mathrm{L}$ of $(1.33 \mathrm{mmol})$ of methyl phenylacetate was dissolved in $5 \mathrm{~mL}$ THF. The reaction mixture was cooled to -78 ${ }^{\circ} \mathrm{C}$, and $107 \mu \mathrm{L}$ of $1 \mathrm{M} \mathrm{LDA}$ solution in THF $(2 \mathrm{mmol})$ was added. The mixture was stirred at $-78{ }^{\circ} \mathrm{C}$ for $30 \mathrm{~min}$, followed by the addition of $141 \mu \mathrm{L}$ of $(1.33 \mathrm{mmol})$ valeraldehyde. The crude product was quenched at $0{ }^{\circ} \mathrm{C}$ with an $\mathrm{NH}_{4} \mathrm{Cl}$ solution, and the aqueous phase was washed 3 times with EtOAc and dried over $\mathrm{Mg}_{2} \mathrm{SO}_{4}$. The product was purified by chromatography on silica gel, eluting with a gradient of hexane/EtOAc. Fractions containing the product were combined, and the solvent was evaporated under reduced pressure (yield: $42 \mathrm{mg}$, $13 \%) .{ }^{1} \mathrm{H}$ NMR $(300 \mathrm{MHz}$, chloroform- $d$ ): $\delta 7.42-7.28(\mathrm{~m}, 43 \mathrm{H})$, 4.24-4.17 (m, 1H), $3.69(\mathrm{~s}, 3 \mathrm{H}), 3.60(\mathrm{~d}, J=6.3 \mathrm{~Hz}, 1 \mathrm{H}), 2.42(\mathrm{~s}$, $1 \mathrm{H}), 1.42-1.26(\mathrm{~m}, 6 \mathrm{H})$, and $0.90(\mathrm{t}, J=7.1 \mathrm{~Hz}, 4 \mathrm{H}) .{ }^{13} \mathrm{C}$ NMR $(75$ $\mathrm{MHz}$, chloroform- $d$ ): $\delta 173.7,135.0,129.1,128.6,127.7,72.1,57.1$, 52.0, 34.1, 27.8, 22.5, and 13.9. LCMS (method 1): $R_{t}=1.328 \mathrm{~min}$; HRMS (ESIpos): $m / z[\mathrm{M}+\mathrm{Na}]^{+}$calcd for $\mathrm{C}_{12} \mathrm{H}_{16} \mathrm{O}_{3}, 231.0992$; found, 231.0986.

To $2 \mathrm{~mL}$ of a DCM solution at $-78{ }^{\circ} \mathrm{C}, 50 \mu \mathrm{L}$ of $(0.71 \mathrm{mmol})$ of DMSO and $52 \mu \mathrm{L}$ of $(0.53 \mathrm{mmol})$ of oxalyl chloride were added, and the mixture was stirred for $10 \mathrm{~min}$. Afterward, $42 \mathrm{mg}$ of $(0.18 \mathrm{mmol})$ of methyl 3-hydroxy-2-phenylheptanoate together with $294 \mu \mathrm{L}$ of (2.1 mmol) of trimethylamine in $700 \mu \mathrm{L}$ of DCM were added dropwise at $-78{ }^{\circ} \mathrm{C}$. After $2 \mathrm{~h}$, the mixture was quenched with $2 \mathrm{M} \mathrm{HCl}$, and the aqueous phase was extracted 3 times with DCM. The combined organic phases were dried with $\mathrm{Na}_{2} \mathrm{SO}_{4}, \mathrm{DCM}$ was removed under reduced pressure, and the raw product was obtained as a yellowish oil $(42 \mathrm{mg})$. It was used as the raw product in the last step of the synthesis. $27 \mathrm{mg}$ of $(0.18 \mathrm{mmol})$ ( $1 \mathrm{H}$-1,3-benzimidazol-2-yl)hydrazine was solubilized in $1 \mathrm{~mL}$ of EtOH. After the addition of $42 \mathrm{mg}$ of $(0.18 \mathrm{mmol})$ methyl 3-oxo-2-phenylheptanoate, the reaction mixture was stirred at $75{ }^{\circ} \mathrm{C}$ for $2 \mathrm{~h}$. EtOH was evaporated, and the crude product was solubilized in $\mathrm{ACN} / \mathrm{H}_{2} \mathrm{O}$ and purified by HPLC, eluting in a gradient of $\mathrm{ACN} / \mathrm{H}_{2} \mathrm{O}$ (yield: $13 \mathrm{mg}, 23 \%$ for two steps).
${ }^{1} \mathrm{H}$ NMR (300 MHz, chloroform- $d$ ): $\delta 7.51(\mathrm{t}, J=6.4 \mathrm{~Hz}, 3 \mathrm{H}), 7.47-$ $7.32(\mathrm{~m}, 5 \mathrm{H}), 2.84(\mathrm{t}, J=1901.2,0.0 \mathrm{~Hz}, 3 \mathrm{H}), 1.78-1.66(\mathrm{~m}, 2 \mathrm{H})$, $1.48-1.36(\mathrm{~m}, 2 \mathrm{H})$, and $0.92(\mathrm{t}, J=7.3 \mathrm{~Hz}, 3 \mathrm{H})$. LCMS (method 2): $R_{t}=1.221$ min; MS (ESIpos): $m / z[\mathrm{M}+\mathrm{H}]^{+} 333.2$.

Compound 20: 2-(4-Bromo-1H-pyrazol-1-yl)-1H-benzo[d]imidazole in Two Steps. $88 \mathrm{mg}$ of $(0.24 \mathrm{mmol})$ 2-bromo-1-((2(trimethylsilyl)ethoxy)methyl)- $1 \mathrm{H}$-benzo[d]imidazole was dissolved in $0.5 \mathrm{~mL}$ of DMF. $232 \mathrm{mg}$ of $(0.71 \mathrm{mmol}) \mathrm{Cs}_{2} \mathrm{CO}_{3}$ and $50 \mathrm{mg}$ of (0.24 mmol) 4-bromo-pyrazole were then added. The mixture was stirred at $80{ }^{\circ} \mathrm{C}$ for $2 \mathrm{~h}$ and quenched with $1 \mathrm{~mL}$ of $\mathrm{H}_{2} \mathrm{O}$. The aqueous phase was extracted 3 times with $\mathrm{Et}_{2} \mathrm{O}$. The combined organic phases were dried with $\mathrm{Na}_{2} \mathrm{SO}_{4}$, and the crude product was obtained as a yellowish oil $(99 \mathrm{mg})$. It was dissolved in $1 \mathrm{~mL}$ of $4 \mathrm{M}$ dioxane $/ \mathrm{HCl}$ solution and stirred for $1 \mathrm{~h}$ at $\mathrm{RT}$. After evaporation of the solvent under reduced pressure, the crude product was solubilized in $\mathrm{ACN} / \mathrm{H}_{2} \mathrm{O}$ and purified by HPLC, eluting in a gradient of ACN/ $\mathrm{H}_{2} \mathrm{O}$ (yield: $5.2 \mathrm{mg}, 7 \%$ for two steps). ${ }^{1} \mathrm{H}$ NMR $(300 \mathrm{MHz}$, chloroform- $d): \delta 9.86(\mathrm{~s}, 1 \mathrm{H}), 8.53(\mathrm{~s}, 1 \mathrm{H}), 7.75-7.70(\mathrm{~m}, 2 \mathrm{H}), 7.46$ $(\mathrm{s}, 1 \mathrm{H})$, and $7.33-7.29(\mathrm{~m}, 2 \mathrm{H})$. LCMS (method 2): $R_{t}=1.072 \mathrm{~min}$; MS (ESIpos): $m / z[\mathrm{M}+\mathrm{H}]^{+}$263.0.

Compound 21: 2-(3,5-Dimethyl-1H-pyrazol-1-yl)-1H-1,3-benzimidazole (Rabenzazole). Rabenzazole was commercially sourced from Alfa Chemistry (Cat. No. ACM40341046) and used without further purification.

Compound 22: 1-(1H-1,3-Benzodiazol-2-yl)-3-methyl-1H-pyrazol-5-amine. Compound $\mathbf{2 2}$ was commercially sourced from MolPort SIA (Cat. No. MP-000-490-277) and used without further purification.

Compound 23: 1-(1H-1,3-Benzodiazol-2-yl)-3-methyl-4-phenyl$1 \mathrm{H}$-pyrazol-5-amine. Compound $\mathbf{2 3}$ was commercially sourced from MolPort SIA (Cat. No. MP-000-476-058) and used without further purification.

Compound 24: 1-(Benzo[d]thiazol-2-yl)-3-methyl-4-phenyl-1Hpyrazol-5-ol. $48 \mathrm{mg}$ of $(0.29 \mathrm{mmol})$ 2-hydrazinobenzothiazole was solubilized in $4 \mathrm{~mL}$ of EtOH. After addition of $50 \mathrm{mg}$ of $(0.23 \mathrm{mmol})$ ethyl-2-phenylacetoacetate, the reaction mixture was stirred at $80{ }^{\circ} \mathrm{C}$ for $2 \mathrm{~h}$. EtOH was evaporated, and the crude product was solubilized in $\mathrm{ACN} / \mathrm{H}_{2} \mathrm{O}$ and purified by HPLC, eluting in a gradient of ACN/ $\mathrm{H}_{2} \mathrm{O}$ (yield: $\left.16 \mathrm{mg}, 18 \%\right) .{ }^{1} \mathrm{H}$ NMR $(300 \mathrm{MHz}$, chloroform- $d): \delta$ 7.90-7.79 (m, 2H), 7.66-7.55 (m, 2H), 7.54-7.42 (m, 3H), 7.42$7.28(\mathrm{~m}, 2 \mathrm{H})$, and $2.45(\mathrm{~s}, 3 \mathrm{H}) .{ }^{13} \mathrm{C}$ NMR $(75 \mathrm{MHz}, \mathrm{CDCl} 3): \delta$ 152.2 , 148.5, 142.6, 141.9, 139.6, 130.9, 128.5, 127.9, 126.9, 126.3, 124.7, 121.7, 121.2, and 14.5. LCMS (method 1): $R_{t}=1.418 \mathrm{~min}$; HRMS (ESIpos): $m / z[\mathrm{M}+\mathrm{H}]^{+}$calcd for $\mathrm{C}_{17} \mathrm{H}_{13} \mathrm{~N}_{3} \mathrm{OS}$, 308.0852; found, 308.0852 .

Compound 25: 3-Methyl-1-(1-methyl-1H-benzo[d]imidazol-2yl)-4-phenyl-1H-pyrazol-5-ol. $557.8 \mathrm{mg}$ of (0.29 mmol) 2-hydrazino-1-methyl-1 $H$-benzimidazole hydrochloride was solubilized in $4 \mathrm{~mL}$ of EtOH. $50 \mathrm{mg}$ of $(0.29 \mathrm{mmol})$ ethyl-2-acetylpent-4-enoate was added, and the mixture was heated to $80^{\circ} \mathrm{C}$. After $2 \mathrm{~h}, \mathrm{EtOH}$ was removed under reduced pressure, and the crude product was solubilized in $2 \mathrm{~mL}$ of $\mathrm{ACN} / \mathrm{H}_{2} \mathrm{O}$. The product was purified by HPLC, eluting in a gradient of ACN $/ \mathrm{H}_{2} \mathrm{O}$ (yield: $31.5 \mathrm{mg}, 35 \%$ ). ${ }^{1} \mathrm{H}$ NMR (300 MHz, chloroform- $d$ ): $\delta 8.77(\mathrm{~s}, 1 \mathrm{H}), 7.68-7.57(\mathrm{~m}, 3 \mathrm{H})$, 7.48-7.34 (m, 5H), 7.31-7.25 (m, 1H), $4.29(\mathrm{~s}, 3 \mathrm{H})$, and $2.44(\mathrm{~s}$, $3 \mathrm{H}) .{ }^{13} \mathrm{C}$ NMR (75 MHz, chloroform- $d$ ): $\delta 155.5,151.3,145.1,136.4$, $133.1,131.6,128.4,127.8,125.9,123.8,123.1,117.0,109.6,101.5$, 32.7, and 14.6. LCMS (method 1): $R_{t}=1.438$ min; HRMS (ESIpos): $m / z[\mathrm{M}+\mathrm{H}]^{+}$calcd for $\mathrm{C}_{18} \mathrm{H}_{16} \mathrm{~N}_{4} \mathrm{O}, 305.1397$; found, 305.1394 .

Compound 26: 3-Methyl-4-phenyl-1-(pyridin-2-yl)-1H-pyrazol-5ol. $13.3 \mathrm{mg}$ of $(0.13 \mathrm{mmol})$ 2-hydrazinopyridine was solubilized in 0.5 $\mathrm{mL}$ of $\mathrm{MeOH}$. After addition of $25 \mathrm{mg}$ of $(0.13 \mathrm{mmol})$ ethyl-2benzylactoacetate, the reaction mixture was stirred at $45{ }^{\circ} \mathrm{C}$ for $2 \mathrm{~h}$. $\mathrm{MeOH}$ was evaporated, and the crude product was purified by HPLC, eluting in a gradient of $\mathrm{ACN} / \mathrm{H}_{2} \mathrm{O}$ (yield: $11 \mathrm{mg}, 36 \%$ ). ${ }^{1} \mathrm{H}$ NMR $\left(300 \mathrm{MHz}, \mathrm{DMSO}-d_{6}\right): \delta 12.39(\mathrm{~s}, 1 \mathrm{H}), 8.63-8.35(\mathrm{~m}, 2 \mathrm{H}), 8.02-$ $7.87(\mathrm{~m}, 1 \mathrm{H}), 7.60(\mathrm{~d}, J=6.4 \mathrm{~Hz}, 2 \mathrm{H}), 7.44-7.31(\mathrm{~m}, 2 \mathrm{H}), 7.31-$ $7.14(\mathrm{~m}, 2 \mathrm{H})$, and $2.38(\mathrm{~s}, 3 \mathrm{H}) .{ }^{13} \mathrm{C}$ NMR $\left(75 \mathrm{MHz}\right.$, DMSO- $\left.d_{6}\right): \delta$ $160.9,148.6,147.8,146.0,139.3,132.7,128.5,127.7,127.7,125.8$, 120.6, 111.9, and 12.6. LCMS (method 1): $R_{t}=1.783$ min; HRMS 
(ESIpos): $m / z[\mathrm{M}+\mathrm{H}]^{+}$calcd for $\mathrm{C}_{15} \mathrm{H}_{13} \mathrm{~N}_{3} \mathrm{O}, 252.1131$; found, 252.1137.

Compound 27: 4-Benzyl-3-methyl-1-(pyridin-2-yl)-1H-pyrazol-5ol. $19.8 \mathrm{mg}$ of $(0.18 \mathrm{mmol})$ 2-hydrazinopyridine was solubilized in 4 $\mathrm{mL}$ of EtOH. After addition of $40 \mathrm{mg}$ of $(0.18 \mathrm{mmol})$ ethyl-2benzylactoacetate, the reaction mixture was stirred at $80^{\circ} \mathrm{C}$ for $2 \mathrm{~h}$. EtOH was evaporated, and the crude product was purified by HPLC, eluting in a gradient of $\mathrm{ACN} / \mathrm{H}_{2} \mathrm{O}$ (yield: $38.8 \mathrm{mg}, 80 \%$ ). ${ }^{1} \mathrm{H}$ NMR $(300 \mathrm{MHz}$, chloroform- $d$ ): $\delta 8.24(\mathrm{~d}, J=4.9 \mathrm{~Hz}, 1 \mathrm{H}), 7.93(\mathrm{~d}, J=8.4$ $\mathrm{Hz}, 1 \mathrm{H}), 7.88-7.79(\mathrm{~m}, 1 \mathrm{H}), 7.33-7.29(\mathrm{~m}, 4 \mathrm{H}), 7.25-7.16(\mathrm{~m}$, $1 \mathrm{H}), 7.14-7.07(\mathrm{~m}, 1 \mathrm{H}), 3.74(\mathrm{~s}, 2 \mathrm{H})$, and $2.17(\mathrm{~s}, 3 \mathrm{H}) .{ }^{13} \mathrm{C}$ NMR $(75 \mathrm{MHz}$, chloroform- $d$ ): $\delta 154.7,153.5,150.7,145.2,140.6,139.7$, $128.3,128.1,125.8,119.5,111.6,100.1,27.5$, and 12.8. LCMS (method 1): $R_{t}=1.429$ min; HRMS (ESIpos): $m / z[\mathrm{M}+\mathrm{H}]^{+}$calcd for $\mathrm{C}_{16} \mathrm{H}_{15} \mathrm{~N}_{3} \mathrm{O}$, 266.1288; found, 266.1276.

Compound 28: 4-Allyl-3-methyl-1-(pyridin-2-yl)-1H-pyrazol-5-ol. $32 \mathrm{mg}$ of $(0.29 \mathrm{mmol})$ 2-hydrazinopyridine was solubilized in $4 \mathrm{~mL}$ of EtOH. $50 \mathrm{mg}$ of $(0.29 \mathrm{mmol})$ ethyl-2-acetylpent-4-enoate was added, and the mixture was heated to $80^{\circ} \mathrm{C}$. After $2 \mathrm{~h}, \mathrm{EtOH}$ was removed under reduced pressure, and the crude product was solubilized in 2 $\mathrm{mL}$ of $\mathrm{ACN} / \mathrm{H}_{2} \mathrm{O}$. The product was purified by HPLC, eluting in a gradient of $\mathrm{ACN} / \mathrm{H}_{2} \mathrm{O}$ (yield: $\left.15 \mathrm{mg}, 24 \%\right) .{ }^{1} \mathrm{H}$ NMR $(300 \mathrm{MHz}$, chloroform- $d): \delta 8.24(\mathrm{~d}, J=4.96 \mathrm{~Hz}, 1 \mathrm{H}), 7.91(\mathrm{~d}, J=8.32 \mathrm{~Hz}, 1 \mathrm{H})$, $7.87-7.79(\mathrm{~m}, 1 \mathrm{H}), 7.13-7.08(\mathrm{~m}, 1 \mathrm{H}), 5.92(\mathrm{ddt}, J=16.1,9.9,5.9$ $\mathrm{Hz}, 1 \mathrm{H}), 5.11-4.99(\mathrm{~m}, 2 \mathrm{H}), 3.12(\mathrm{dt}, J=5.9,1.8 \mathrm{~Hz}, 2 \mathrm{H})$, and 2.21 $(\mathrm{s}, 3 \mathrm{H}) \cdot{ }^{13} \mathrm{C}$ NMR $(75 \mathrm{MHz}$, chloroform-d): $\delta 154.2,153.6,150.8$, 145.2, 139.6, 136.0, 119.3, 114.5, 111.5, 98.2, 25.7, and 12.7. LCMS (method 1): $R_{t}=1.329$ min; HRMS (ESIpos): $m / z[\mathrm{M}+\mathrm{H}]^{+}$calcd for $\mathrm{C}_{18} \mathrm{H}_{16} \mathrm{~N}_{4} \mathrm{O}$, 305.1397; found, 305.1383 .

Compound 29: 1-(6-Chloropyridazin-3-yl)-3-methyl-4-phenyl$1 \mathrm{H}$-pyrazol-5-ol. $35 \mathrm{mg}$ of $(0.24 \mathrm{mmol})$ 3-chloro-6-hydrazinopyridazine was solubilized in $4 \mathrm{~mL}$ of EtOH at RT. After addition of $50 \mathrm{mg}$ of $(0.24 \mathrm{mmol})$ ethyl-2-phenylacetoacetate, the reaction mixture was stirred at $80{ }^{\circ} \mathrm{C}$ for $2 \mathrm{~h}$. EtOH was evaporated, and the crude product was solubilized in $\mathrm{ACN} / \mathrm{H}_{2} \mathrm{O}$ and purified by HPLC, eluting in a gradient of $\mathrm{ACN} / \mathrm{H}_{2} \mathrm{O}$ (yield: $10 \mathrm{mg}, 14 \%$ ). ${ }^{1} \mathrm{H}$ NMR $(300 \mathrm{MHz}$, chloroform $-d): \delta 8.19(\mathrm{~d}, J=7.0 \mathrm{~Hz}, 1 \mathrm{H}), 7.68(\mathrm{~d}, J=9.5$ $\mathrm{Hz}, 1 \mathrm{H}), 7.56(\mathrm{~d}, J=7.6 \mathrm{~Hz}, 2 \mathrm{H}), 7.48-7.40(\mathrm{~m}, 2 \mathrm{H}), 7.31(\mathrm{~d}, J=$ $7.3 \mathrm{~Hz}, 1 \mathrm{H})$, and $2.43(\mathrm{~s}, 3 \mathrm{H}) .{ }^{13} \mathrm{C}$ NMR $\left(75 \mathrm{MHz}, \mathrm{DMSO}-d_{6}\right): \delta$ $161.9,152.4,151.0,148.7,132.0,131.3,128.6,127.8,126.1,119.8$, 104.1, and 12.7. LCMS (method 1): $R_{t}=1.314 \mathrm{~min}$; HRMS (ESIpos): $m / z[\mathrm{M}+\mathrm{H}]^{+}$calcd for $\mathrm{C}_{14} \mathrm{H}_{11} \mathrm{~N}_{4} \mathrm{O}, 287.0694$; found, 287.0692.

Compound 30: 2-(5-Hydroxy-3-methyl-4-phenyl-1H-pyrazol-1yl)-1H-benzo[d]imidazole-5-carboxylic Acid in Two Steps. $20 \mathrm{mg}$ of $(0.1 \mathrm{mmol})$ of methyl 2-hydrazineyl-1H-benzo[d]imidazole-5-carboxylate was solubilized in $0.5 \mathrm{~mL}$ of $\mathrm{MeOH}$ at RT. After the addition of $20 \mathrm{mg}$ of $(0.1 \mathrm{mmol})$ ethyl-2-phenylacetoacetate, the reaction mixture was stirred at $45{ }^{\circ} \mathrm{C}$ for $2 \mathrm{~h}$. $\mathrm{MeOH}$ was evaporated under reduced pressure, the crude methyl 2-(5-hydroxy-3-methyl-4-phenyl-1Hpyrazol-1-yl)-1 $H$-benzo[d]imidazole-5-carboxylate was dissolved in 1 $\mathrm{mL}$ of THF and $1 \mathrm{~mL}$ of a $1 \mathrm{M} \mathrm{LiOH}$ solution was added at RT. After saponification, the crude product was solubilized in $\mathrm{ACN} / \mathrm{H}_{2} \mathrm{O}$ and purified by HPLC, eluting in a gradient of $\mathrm{ACN} / \mathrm{H}_{2} \mathrm{O}$ (yield: $2 \mathrm{mg}$, 14\%). LCMS (method 2): $R_{t}=1.022 \mathrm{~min}$; MS (ESIpos): $\mathrm{m} / z[\mathrm{M}+$ $\mathrm{H}]^{+}$335.1.

Protein Purification. Catalytic domains of KDM4 isoforms were expressed either as $\mathrm{N}$-terminal hexahistidine $\left(\mathrm{His}_{6}\right)$-tagged proteins (KDM4A/E) or as N-terminal thioredoxin/His 6 -tagged fusion proteins (KDM4D). KDM4A (residues 1-359) was expressed from the pQTEV expression vector. The plasmid (pNic28-Bsa4-based) encoding KDM4E residues 1-337 was a gift from the Structural Genomics Consortium (Oxford, UK). KDM4D residues 1-378 was expressed from the pNH-TrxT expression vector. Proteins were expressed in Escherichia coli strain BL21 (DE3)-R3 containing the pRARE2 plasmid, purified using $\mathrm{Ni}^{2+}$ affinity and $\mathrm{S} 200$ gel filtration chromatography, and processed with TEV protease for affinity tag removal exactly as previously described. ${ }^{24,32,35}$

Enzyme Activity Assays. The KDM4 enzyme activity was measured by a fluorescence-based, formaldehyde dehydrogenase
(FDH)-coupled enzyme assay ${ }^{36}$ and by a calf thymus histone (CTH)-ELISA, ${ }^{18}$ as previously described. The processed data were analyzed for $\mathrm{IC}_{50}$ values using either the log (inhibitor) vs response (with variable slope) or biphasic dose-response models in GraphPad Prism 5.01.

Mechanism of Action Studies. The FDH-based KDM4 activity assay was used to calculate the kinetic values of $K_{\mathrm{m}}$ and $V_{\max }$ for the H3K9me3 peptide substrate and for the $\alpha$-KG cofactor using initial velocity data and the Michaelis-Menten fitting model of GraphPad Prism 5.01. Fitting procedures and kinetic constant determinations were then repeated on the initial velocity data collected in the presence of either $1,5,10$, or $20 \mu \mathrm{M}$ of the KDM4 inhibitor, compound 15. The $\alpha$-KG-competitive KDM4 inhibitor 2,4-PDCA was characterized in parallel as a validated control. Double reciprocal plots of initial velocity data were generated in tandem to serve as qualitative assessments of enzyme inhibition.

Protein Crystallization and Ligand-Soaking Experiments. Crystals of KDM4A were grown using the hanging-drop vapordiffusion method at $277 \mathrm{~K}$. The reservoir solution comprised $20 \%$ (w/ v) PEG 3350, $10 \mathrm{mM} \mathrm{NiCl}$, and $0.1 \mathrm{M}$ citrate buffer $\mathrm{pH} 5.5$; KDM4A was concentrated to $11.5 \mathrm{mg} / \mathrm{mL}$ in a solution comprising $0.5 \mathrm{M} \mathrm{NaCl}, 5 \%$ (v/v) glycerol, $1 \mathrm{mM}$ TCEP, and $10 \mathrm{mM}$ HEPES $\mathrm{pH}$ 7.5. Crystallization drops were prepared by mixing ice-cold protein solution with ice-cold reservoir solution at a 2:1 ratio of protein-toreservoir solution. Crystallization was accelerated by micro-seeding using a cat whisker for seed transfer. Inhibitors (compounds $\mathbf{2 6}$ and 30) were soaked overnight into KDM $4 \mathrm{~A}$ crystals by introducing a 0.3 $\mu \mathrm{L}$ volume of inhibitor stock solution (100 mM ligand in $100 \%$ DMSO) to a $2.2 \mu \mathrm{L}$ drop containing crystals plus reservoir solution [12 mM final ligand concentration, 12\% (v/v) DMSO]. The cryosolutions comprised reservoir solution plus ethylene glycol (EDO), increased step-wise by $5 \%$ increments, from an initial concentration of $5 \%(\mathrm{v} / \mathrm{v})$ EDO up to a final concentration of $20 \%(\mathrm{v} / \mathrm{v})$. Crystals were immersed for $1 \mathrm{~s}$ in each ice-cold cryo-solution and carefully transferred to higher EDO concentrations before flash cooling in liquid nitrogen.

KDM4D crystals were grown using the sitting-drop vapor-diffusion method at $291 \mathrm{~K}$. First, KDM4D was concentrated to $19 \mathrm{mg} / \mathrm{mL}$ in a solution comprising $0.5 \mathrm{M} \mathrm{NaCl}, 5 \%(\mathrm{v} / \mathrm{v})$ glycerol, $1 \mathrm{mM}$ TCEP, and $10 \mathrm{mM}$ HEPES buffer $\mathrm{pH}$ 7.5. The reservoir solution comprised $24 \%$ (w/v) PEG 3350, $180 \mathrm{mM}$ ammonium sulfate, and $0.1 \mathrm{M}$ HEPES $\mathrm{pH}$ 7.0. A Gryphon crystallization robot (Art Robbins Instruments) was used to mix $0.4 \mu \mathrm{L}$ of the reservoir solution with an equal volume of protein solution on the surface of a 96-well low profile Intelli-Plate (Art Robbins Instruments). KDM4D crystals were presoaked for $10 \mathrm{~min}$ directly in well solutions by addition of $10 \mathrm{mM}$ $\mathrm{NiCl}_{2}$ and subsequently transferred to a ligand-soaking solution comprising the reservoir solution plus $50 \mathrm{mM}$ compound $\mathbf{1}$ and a total of $5 \%(\mathrm{v} / \mathrm{v})$ DMSO. The crystals were soaked overnight at $18{ }^{\circ} \mathrm{C}$. Finally, the soaked crystals were cryo-protected by quick immersion into the reservoir solution supplemented with $20 \%$ EDO and flash cooled in liquid nitrogen.

Energy-Dispersive Fluorescence Spectra. Energy-dispersive fluorescence spectra were acquired at room temperature on the MX beamline BL14.1 ${ }^{37}$ of the BESSY II synchrotron, operated by the Helmholtz-Zentrum für Materialien und Energie in Berlin, Germany. KDM4D crystals were presoaked in $\mathrm{NiCl}_{2}$, washed twice in the reservoir solution without $\mathrm{Ni}^{2+}$ ions, mounted on nylon loops, and inserted into capillaries for measurement. The peaks were identified using XFEplot (https://www.helmholtz-berlin.de/forschung/oe/ps/ macromolecular-crystallography/hzb-mx-software/xfeplot/index en. $\mathrm{html})$. The energy-dispersive fluorescence spectra were measured at three different positions within a crystal ( $2 \mathrm{~s}$ count time). The crystals were subsequently unmounted and gently transferred to the KDM4D ligand-soaking solution and incubated overnight. As a control, $\mathrm{Ni}^{2+}$ saturated KDM4D crystals were soaked overnight as indicated above, but in the reservoir solution supplemented with 5\% (v/v) DMSO. The following day, the crystals were washed twice in a nonsupplemented reservoir solution and measured as described above for initial measurements. Single-crystal measurements were averaged and 
separately normalized to the intensity of the highest observable peak (corresponding to structural $\mathrm{Zn}^{2+}$ ions in the case of KDM4D), both before and after soaking (the amount of $\mathrm{Zn}^{2+}$ ions in KDM4D crystals is assumed to be unaffected by ligand soaking).

Data Collection, Processing, Structure Determination, and Refinement. X-ray diffraction data were collected on the MX beamline BL14.1 $1^{37}$ at BESSY II in Berlin using a PILATUS $6 \mathrm{M}$ detector. Data were integrated and scaled using the XDSAPP software. ${ }^{38,39}$ The structures were solved by molecular replacement using the existing models of KDM4 enzymes (PDB-IDs 3PDQ for KDM4A and 4HON for KDM4D) and the program Phaser. ${ }^{40}$ The updated model (molecular replacement solution) was initially refined with Refmac $^{41}$ and subsequently by phenix.refine. ${ }^{42}$ The final model was generated after cycles of manual adjustment using Coot, ${ }^{43}$ validated, and deposited into the Protein Data Bank (PDB-IDs 6G5W and 6G5X).

Cell Culture. Human primary PCa cell lines (LnCaP and DU145) and the non-disease control, human prostate epithelial cell line (HuPrEC, Merck Millipore), were propagated according to established protocols, either from ATCC (LnCaP, DU145) or from Merck Millipore (HuPrEC).

Cytotoxicity Assays. Cytotoxicity of selected KDM4 inhibitors against PCa cell lines and against a HuPrEC control cell line was assessed by the alamarBlue assay as previously described. ${ }^{18}$

Reporter Gene Assay. A reporter gene construct was generated by PCR amplification of the PSA promoter and enhancer regions from plasmid pDRIVE5Lucia-PSA-hPSA (Invivogen, San Diego, CA) using forward primer: 5'-attggtaccCCTCTAGAAATCTAGCTGATATAG-3' and reverse primer: 5'-gttctcgaGGTGACACAGCTCTCCGGGTG-3'. The PCR product was digested with $\mathrm{KpnI} / \mathrm{XhoI}$ and ligated into the similarly-digested pGL4.10 reporter vector (Promega, Madison, WI). The resulting construct (PSApGL4.10) yielded a firefly luciferase reporter gene under the control of the PSA promoter. AR-positive $\mathrm{LnCaP}$ cells were used for transfection experiments. A total of 14,000 cells were seeded into 10 replicate wells of a 96-well plate containing $100 \mu \mathrm{L}$ of RPMI medium plus 10\% FBS (Thermo Fisher Scientific, Waltham, MA) and $1 \times$ MEM non-essential amino acids. Cells were grown for $48 \mathrm{~h}$ at $37^{\circ} \mathrm{C}$ and $5 \% \mathrm{CO}_{2}$ before being transfected with $100 \mathrm{ng}$ of either PSApGL4.10 or empty vector using Lipofectamine LTX and the Plus reagent (Thermo Fisher Scientific, Waltham, MA), according to the manufacturer's protocol. The transfected cells were grown for $24 \mathrm{~h}$ prior to the addition of KDM4 inhibitors or the addition of DMSO alone $[0.5 \%(\mathrm{v} / \mathrm{v})]$ as vehicle control. Each test condition was repeated in biological replicates of eight. Cells were then grown under test conditions for an additional $48 \mathrm{~h}$ prior to lysis and measurement of luminescence. Cell lysis and luminescence measurements were performed using a Beetle-Juice luminescence kit (P.J.K. GmbH, Kleinblittersdorf, DE) on a FluoStar Optima plate reader (BMG Labtech, Ortenberg, DE).

Gene Expression Analysis by qPCR. LnCaP cells were grown in triplicate wells of a 6-well plate at $37^{\circ} \mathrm{C}$ and $5 \% \mathrm{CO}_{2}$ until reaching $75 \%$ confluency. At this point, compounds (ML324, compound 15, or DMSO control) were added to the growth media, and the cells were grown for an additional $48 \mathrm{~h}$ prior to RNA extraction and downstream processing. Where applicable, DMSO was present at $0.5 \%(\mathrm{v} / \mathrm{v})$. Culture media were then aspirated and cells were lysed in Trizol Plus reagent (Life Technologies). The resulting RNA was purified using the PureLink RNA Mini Kit (Life Technologies) including on-column digestion with DNAse by the PureLink DNAse Kit (Life Technologies). RNA quality was assessed by agarose gel electrophoresis and quantified by absorbance readings at $260 \mathrm{~nm}$ using a Nanodrop instrument. Complementary DNA (cDNA) was synthesized with the High Capacity RNA-to-cDNA kit (Applied Biosystems) containing random octamer and oligo (dT) primers. PCR was performed on a Bio-Rad CFX96 thermocycler instrument. Expression of PSA was measured relative to the housekeeping gene, hypoxanthine phosphoribosyltransferase 1 (HPRT1), using primers: PSA Fwd: 5'-AAGCTGGAGGCACAACGCACC-3'; PSA-Rev: 5'CCTCCTTGGCTCACAGCCTTCTC-3'; HPRT1 Fwd: 5'-
GCTGAGGATTTGGAAAGGGTG-3'; and HPRT1 Rev: 5'-GCTACAATGTGATGGCCTCC-3'. Gene amplification was measured using the Power SybrGreen PCR Master Mix (Applied Biosystems) and analyzed by thermal melting curves as well as by agarose gel electrophoresis after PCR cycling. Fold differences in gene expression were calculated by the $\Delta \Delta C t$ method $^{44,45}$ and analyzed for statistical significance using GraphPad Prism 5.01 software.

Chromatin Analysis by Western Blot. LnCaP cells were grown and treated with the inhibitor as described below for Nu-ELISA experiments. Cells were then lysed and chromatin purified with a Histone Purification Mini Kit (Active Motif, Carlsbad, CA), according to the manufacturer's protocol. The resulting chromatin $(2 \mu \mathrm{g}$ from each test condition) was loaded on 4-20\% gradient Mini-PROTEAN TGX polyacrylamide gels (Bio-Rad) and separated by SDS-PAGE electrophoresis. Western blot analysis was performed with a monoclonal antibody specific for H3K9me3 (Abcam Ab\#6001). A second antibody (BioVision \#3624) specific for a non-epigenetic epitope in histone $\mathrm{H} 4$ was used as a loading control. An HRPconjugated mouse anti-rabbit IgG was used as a secondary detection antibody (Cell Signaling Technology, Inc.). The band density was measured by densitometry and quantified with ImageJ software. ${ }^{46}$ The changes in chromatin methylation were evaluated relative to untreated cells grown in media alone.

Chromatin Analysis by Nu-ELISA. Cells (LnCaP and DU145 cell lines) were grown in triplicate wells of a 6-well plate. Upon reaching $75 \%$ confluence, the media was changed and replaced with inhibitor-supplemented media. Cells were then grown for an additional $48 \mathrm{~h}$. The medium was then removed, and plates were washed twice with PBS before freezing in liquid nitrogen and storage at $-80{ }^{\circ} \mathrm{C}$ until further analysis. After a freeze-thaw lytic cycle, the cell material was resuspended in MNase buffer $\left(5 \mathrm{mM} \mathrm{NaPO}_{4} \mathrm{pH} 7.0\right.$ and $0.025 \mathrm{mM} \mathrm{CaCl}_{2}$ ) and digested with 2 units of MNase (SigmaAldrich, St. Louis, MO) for $12 \mathrm{~min}$ at $37{ }^{\circ} \mathrm{C}$. The digested material containing nucleosomes was coated into replicate wells $(n=9)$ of a 96-well ELISA plate (Nunc) and incubated overnight at $4{ }^{\circ} \mathrm{C}$. The following day, ELISAs were performed and quantified as previously described. ${ }^{18,30}$

\section{ASSOCIATED CONTENT}

\section{Supporting Information}

The Supporting Information is available free of charge at https://pubs.acs.org/doi/10.1021/acs.jmedchem.1c00693.

Molecular strings formula, QC data for selected compounds, enzyme kinetics fitting statistics, crystallographic data table, additional enzyme inhibition data, and cell-based data (PDF)

Molecular formula strings (CSV)

\section{AUTHOR INFORMATION}

\section{Corresponding Authors}

Udo Heinemann - Max Delbrück Center for Molecular Medicine in the Helmholtz Gemeinschaft (MDC), Berlin 13125, Germany; Phone: (+49) 30 9406-3420; Email: heinemann@mdc-berlin.de; Fax: (+49) 30 94062548

Marc Nazaré - Leibniz-Forschungsinstitut für Molekulare Pharmakologie (FMP), Berlin 13125, Germany; (1) orcid.org/0000-0002-1602-2330; Phone: (+49) 30 9406-3083; Email: nazare@fmp-berlin.de; Fax: (+49) 30 9406-3084

\section{Authors}

David M. Carter - Max Delbrück Center for Molecular Medicine in the Helmholtz Gemeinschaft (MDC), Berlin 13125, Germany 
Edgar Specker - Leibniz-Forschungsinstitut für Molekulare Pharmakologie (FMP), Berlin 13125, Germany

Piotr H. Małecki - Max Delbrück Center for Molecular Medicine in the Helmholtz Gemeinschaft (MDC), Berlin 13125, Germany; Helmholtz-Zentrum Berlin (HZB) Macromolecular Crystallography, Berlin 14109, Germany; Present Address: Department of Structural Biology of Prokaryotic Organisms, Institute of Bioorganic Chemistry, Polish Academy of Sciences, Poznan, 61-704, Poland

Jessica Przygodda - Leibniz-Forschungsinstitut für Molekulare Pharmakologie (FMP), Berlin 13125, Germany

Krystyna Dudaniec - Max Delbrück Center for Molecular Medicine in the Helmholtz Gemeinschaft (MDC), Berlin 13125, Germany

Manfred S. Weiss - Helmholtz-Zentrum Berlin (HZB) Macromolecular Crystallography, Berlin 14109, Germany

Ulrich Gohlke - Max Delbrück Center for Molecular Medicine in the Helmholtz Gemeinschaft (MDC), Berlin 13125, Germany

Complete contact information is available at: https://pubs.acs.org/10.1021/acs.jmedchem.1c00693

\section{Author Contributions}

The manuscript was written through the contributions of all authors. All authors have given approval to the final version of the manuscript.

\section{Notes}

The authors declare no competing financial interest. PDB IDs of new KDM4A X-ray Structures: KDM4A with bound compound 26 (PDB 6G5W), and KDM4A with bound compound 30 (PDB 6G5X).

\section{ACKNOWLEDGMENTS}

This work was funded in part by an MDC-Go-Bio grant awarded to D.M.C. It was performed in part within the framework of the Joint Berlin MX Laboratory, a collaboration between several Berlin research institutions and created to foster structural biology research in the greater Berlin area.

\section{ABBREVIATIONS}

$\mathrm{ACN}$, acetonitrile; $\mathrm{AR}$, androgen receptor; calcd, calculated; cmpd, compound; EtOAc, ethyl acetate; EtOH, ethanol; jmjC, jumonji C domain; KDM, lysine demethylase; $\mathrm{MeOH}$, methanol; PCa, prostate cancer; PSA, prostate-specific antigen

\section{REFERENCES}

(1) D’Oto, A.; Tian, Q. W.; Davidoff, A. M.; Yang, J. Histone Demethylases and Their Roles in Cancer Epigenetics. J. Med. Oncol. Ther. 2016, 1, 34-40.

(2) Doñas, C.; Loyola, A.; Rosemblatt, M. Exploring Epigenetic Drugs in the Regulation of Inflammatory Autoimmune Diseases. In Translational Studies on Inflammation; Nunes, A. C. F., Ed.; IntechOpen: London, 2020; pp 1-25.

(3) Zwergel, C.; Stazi, G.; Mai, A.; Valente, S. Trends of LSD1 Inhibitors in Viral Infections. Future Med. Chem. 2018, 10, 11331136.

(4) Liang, Y.; Vogel, J. L.; Arbuckle, J. H.; Rai, G.; Jadhav, A.; Simeonov, A.; Maloney, D. J.; Kristie, T. M. Targeting the JMJD2 Histone Demethylases to Epigenetically Control Herpesvirus Infection and Reactivation from Latency. Sci. Transl. Med. 2013, 5, $167 \mathrm{ra5}$.

(5) Knipe, D. M.; Lieberman, P. M.; Jung, J. U.; McBride, A. A.; Morris, K. V.; Ott, M.; Margolis, D.; Nieto, A.; Nevels, M.; Parks, R.
J.; Kristie, T. M. Snapshots: Chromatin Control of Viral Infection. Virology 2013, 435, 141-156.

(6) Metzger, E.; Wissmann, M.; Yin, N.; Müller, J. M.; Schneider, R.; Peters, A. H. F. M.; Günther, T.; Buettner, R.; Schüle, R. LSD1 Demethylates Repressive Histone Marks to Promote AndrogenReceptor- Dependent Transcription. Nature 2005, 437, 436-439.

(7) Shin, S.; Janknecht, R. Activation of Androgen Receptor by Histone Demethylases JMJD2A and JMJD2D. Biochem. Biophys. Res. Commun. 2007, 359, 742-746.

(8) Wissmann, M.; Yin, N.; Müller, J. M.; Greschik, H.; Fodor, B. D.; Jenuwein, T.; Vogler, C.; Schneider, R.; Günther, T.; Buettner, R.; Metzger, E.; Schüle, R. Cooperative Demethylation by JMJD2C and LSD1 Promotes Androgen Receptor-Dependent Gene Expression. Nat. Cell Biol. 2007, 9, 347-353.

(9) Coffey, K.; Rogerson, L.; Ryan-Munden, C.; Alkharaif, D.; Stockley, J.; Heer, R.; Sahadevan, K.; O’Neill, D.; Jones, D.; Darby, S.; Staller, P.; Mantilla, A.; Gaughan, L.; Robson, C. N. The Lysine Demethylase, KDM4B, Is a Key Molecule in Androgen Receptor Signalling and Turnover. Nucleic Acids Res. 2013, 41, 4433-4446.

(10) Labbe, R. M.; Holowatyj, A.; Yang, Z. Q. Histone Lysine Demethylase (Kdm) Subfamily 4: Structures, Functions and Therapeutic Potential. Am. J. Transl. Res. 2014, 6, 1-15.

(11) Lee, D. H.; Kim, G. W.; Jeon, Y. H.; Yoo, J.; Lee, S. W.; Kwon, S. H. Advances in Histone Demethylase KDM4 as Cancer Therapeutic Targets. FASEB J. 2020, 34, 3461-3484.

(12) Jambhekar, A.; Anastas, J. N.; Shi, Y. Histone Lysine Demethylase Inhibitors. Cold Spring Harbor Perspect. Med. 2017, 7, a026484.

(13) Lin, H.; Li, Q.; Li, Q.; Zhu, J.; Gu, K.; Jiang, X.; Hu, Q.; Feng, F.; Qu, W.; Chen, Y.; Sun, H. Small Molecule KDM4s Inhibitors as Anti-Cancer Agents. J. Enzyme Inhib. Med. Chem. 2018, 33, 777-793.

(14) McAllister, T. E.; England, K. S.; Hopkinson, R. J.; Brennan, P. E.; Kawamura, A.; Schofield, C. J. Recent Progress in Histone Demethylase Inhibitors. J. Med. Chem. 2016, 59, 1308-1329.

(15) Thinnes, C. C.; England, K. S.; Kawamura, A.; Chowdhury, R.; Schofield, C. J.; Hopkinson, R. J. Targeting Histone Lysine Demethylases - Progress, Challenges, and the Future. Biochim. Biophys. Acta, Gene Regul. Mech. 2014, 1839, 1416-1432.

(16) Wang, L.; Chang, J.; Varghese, D.; Dellinger, M.; Kumar, S.; Best, A. M.; Ruiz, J.; Bruick, R.; Peña-Llopis, S.; Xu, J.; Babinski, D. J.; Frantz, D. E.; Brekken, R. A.; Quinn, A. M.; Simeonov, A.; Easmon, J.; Martinez, E. D. A Small Molecule Modulates Jumonji Histone Demethylase Activity and Selectively Inhibits Cancer Growth. Nat. Commun. 2013, 4, 2035.

(17) Kawamura, A.; Münzel, M.; Kojima, T.; Yapp, C.; Bhushan, B.; Goto, Y.; Tumber, A.; Katoh, T.; King, O. N. F.; Passioura, T.; Walport, L. J.; Hatch, S. B.; Madden, S.; Müller, S.; Brennan, P. E.; Chowdhury, R.; Hopkinson, R. J.; Suga, H.; Schofield, C. J. Highly Selective Inhibition of Histone Demethylases by de Novo Macrocyclic Peptides. Nat. Commun. 2017, 8, 14773.

(18) Carter, D. M.; Specker, E.; Przygodda, J.; Neuenschwander, M.; von Kries, J. P.; Heinemann, U.; Nazaré, M.; Gohlke, U. Identification of a Novel Benzimidazole Pyrazolone Scaffold That Inhibits KDM4 Lysine Demethylases and Reduces Proliferation of Prostate Cancer Cells. SLAS Discovery 2017, 22, 801-812.

(19) Flamme, I.; Oehme, F.; Ellinghaus, P.; Jeske, M.; Keldenich, J.; Thuss, U. Mimicking Hypoxia to Treat Anemia: HIF-Stabilizer BAY 85-3934 (Molidustat) Stimulates Erythropoietin Production without Hypertensive Effects. PLoS One 2014, 9, No. e111838.

(20) Rosen, M. D.; Venkatesan, H.; Peltier, H. M.; Bembenek, S. D.; Kanelakis, K. C.; Zhao, L. X.; Leonard, B. E.; Hocutt, F. M.; Wu, X.; Palomino, H. L.; Brondstetter, T. I.; Haugh, P. V.; Cagnon, L.; Yan, W.; Liotta, L. A.; Young, A.; Mirzadegan, T.; Shankley, N. P.; Barrett, T. D.; Rabinowitz, M. H. Benzimidazole-2-Pyrazole HIF Prolyl 4Hydroxylase Inhibitors as Oral Erythropoietin Secretagogues. ACS Med. Chem. Lett. 2010, 1, 526-529.

(21) England, K. S.; Tumber, A.; Krojer, T.; Scozzafava, G.; Ng, S. S.; Daniel, M.; Szykowska, A.; Che, K.; von Delft, F.; Burgess-Brown, N. A.; Kawamura, A.; Schofield, C. J.; Brennan, P. E. Optimisation of 
a Triazolopyridine Based Histone Demethylase Inhibitor Yields a Potent and Selective KDM2A (FBXL11) Inhibitor. MedChemCom 2014, 5, 1879-1886.

(22) King, O. N. F.; Krojer, T.; Arrowsmith, C. H.; Edwards, A.; Bountra, C.; McDonough, M. A.; Schofield, C. J. Crystal Structure of JMJD2A Complexed with Inhibitor. PDB ID: 4GD4.

(23) Małecki, P. H.; Rüger, N.; Roatsch, M.; Krylova, O.; Link, A.; Jung, M.; Heinemann, U.; Weiss, M. S. Structure-Based Screening of Tetrazolylhydrazide Inhibitors versus KDM4 Histone Demethylases. ChemMedChem 2019, 14, 1828-1839.

(24) Ng, S. S.; Kavanagh, K. L.; McDonough, M. A.; Butler, D.; Pilka, E. S.; Lienard, B. M. R.; Bray, J. E.; Savitsky, P.; Gileadi, O.; von Delft, F.; Rose, N. R.; Offer, J.; Scheinost, J. C.; Borowski, T.; Sundstrom, M.; Schofield, C. J.; Oppermann, U. Crystal Structures of Histone Demethylase JMJD2A Reveal Basis for Substrate Specificity. Nature 2007, 448, 87-91.

(25) Dougall, I. G.; Unitt, J. Evaluation of the Biological Activity of Compounds: Techniques and Mechanism of Action Studies. The Practice of Medicinal Chemistry, 4th ed.; Elsevier Inc., 2015; pp 15-43.

(26) Nishio, M.; Umezawa, Y.; Fantini, J.; Weiss, M. S.; Chakrabarti, P. CH- $\pi$ Hydrogen Bonds in Biological Macromolecules. Phys. Chem. Chem. Phys. 2014, 16, 12648-12683.

(27) Rai, G.; Kawamura, A.; Tumber, A.; Liang, Y.; Vogel, J. L.; Arbuckle, J. H.; Rose, N. R.; Dexheimer, T. S.; Foley, T. L.; King, O. N.; Quinn, A.; Mott, B. T.; Schofield, C. J.; Oppermann, U.; Jadhav, A.; Simeonov, A.; Kristie, T. M.; Maloney, D. J. Discovery of ML324, a JMJD2 Demethylase Inhibitor with Demonstrated Antiviral Activity. Probe Reports from the NIH Molecular Libraries Program, 2012. https://www.ncbi.nlm.nih.gov/books/NBK169450/.

(28) Wolf, D. A.; Schulz, P.; Fittler, F. Transcriptional Regulation of Prostate Kallikrein-like Genes by Androgen. Mol. Endocrinol. 1992, 6, $753-762$.

(29) Matsuoka, T.; Shigemura, K.; Yamamichi, F.; Fujisawa, M.; Kawabata, M.; Shirakawa, T. Detection of Tumor Markers in Prostate Cancer and Comparison of Sensitivity between Real Time and Nested PCR. Kobe J. Med. Sci. 2012, 58, E51-E59.

(30) Dai, B.; Giardina, C.; Rasmussen, T. P. Quantitation of Nucleosome Acetylation and Other Histone Posttranslational Modifications Using Microscale NU-ELISA. Methods Mol. Biol. 2013, 981, 167-176.

(31) King, O. N.; Maloney, D.; Tumber, A.; Rai, G.; Jadhav, A.; Clifton, I.; Heightman, T.; Simeonov, A.; McDonough, M.; Schofield, C. J. Crystal Structure of JMJD2A Complexed with Inhibitor. PDB ID: 3RVH.

(32) Krishnan, S.; Trievel, R. C. Structural and Functional Analysis of JMJD2D Reveals Molecular Basis for Site-Specific Demethylation among JMJD2 Demethylases. Structure 2013, 21, 98-108.

(33) Bavetsias, V.; Lanigan, R. M.; Ruda, G. F.; Atrash, B.; McLaughlin, M. G.; Tumber, A.; Mok, N. Y.; Le Bihan, Y.-V.; Dempster, S.; Boxall, K. J.; Jeganathan, F.; Hatch, S. B.; Savitsky, P.; Velupillai, S.; Krojer, T.; England, K. S.; Sejberg, J.; Thai, C.; Donovan, A.; Pal, A.; Scozzafava, G.; Bennett, J. M.; Kawamura, A.; Johansson, C.; Szykowska, A.; Gileadi, C.; Burgess-Brown, N. A.; Von Delft, F.; Oppermann, U.; Walters, Z.; Shipley, J.; Raynaud, F. I.; Westaway, S. M.; Prinjha, R. K.; Fedorov, O.; Burke, R.; Schofield, C. J.; Westwood, I. M.; Bountra, C.; Müller, S.; Van Montfort, R. L. M.; Brennan, P. E.; Blagg, J. 8-Substituted Pyrido[3,4-d]Pyrimidin-4(3H)One Derivatives As Potent, Cell Permeable, KDM4 (JMJD2) and KDM5 (JARID1) Histone Lysine Demethylase Inhibitors. J. Med. Chem. 2016, 59, 1388-1409.

(34) Pearce, N. M.; Krojer, T.; Bradley, A. R.; Collins, P.; Nowak, R. P.; Talon, R.; Marsden, B. D.; Kelm, S.; Shi, J.; Deane, C. M.; Von Delft, F. A Multi-Crystal Method for Extracting Obscured Crystallographic States from Conventionally Uninterpretable Electron Density. Nat. Commun. 2017, 8, 15123.

(35) Rose, N. R.; Ng, S. S.; Mecinović, J.; Liénard, B. M. R.; Bello, S. H.; Sun, Z.; Mcdonough, M. A.; Oppermann, U.; Schofield, C. J. Inhibitor Scaffolds for 2- Oxoglutarate-Dependent Histone Lysine Demethylases. J. Med. Chem. 2008, 51, 7053-7056.
(36) Sakurai, M.; Rose, N. R.; Schultz, L.; Quinn, A. M.; Jadhav, A.; Ng, S. S.; Oppermann, U.; Schofield, C. J.; Simeonov, A. A Miniaturized Screen for Inhibitors of Jumonji Histone Demethylases. Mol. BioSyst. 2010, 6, 357-364.

(37) Mueller, U.; Förster, R.; Hellmig, M.; Huschmann, F. U.; Kastner, A.; Malecki, P.; Pühringer, S.; Röwer, M.; Sparta, K.; Steffien, M.; Ühlein, M.; Wilk, P.; Weiss, M. S. The Macromolecular Crystallography Beamlines at BESSY II of the Helmholtz-Zentrum Berlin: Current Status and Perspectives. Eur. Phys. J. Plus 2015, 130, 141.

(38) Kabsch, W. XDS. Acta Crystallogr., Sect. D: Biol. Crystallogr. 2010, 66, 125-132.

(39) Sparta, K. M.; Krug, M.; Heinemann, U.; Mueller, U.; Weiss, M. S. Xdsapp2.0. J. Appl. Crystallogr. 2016, 49, 1085-1092.

(40) McCoy, A. J.; Grosse-Kunstleve, R. W.; Adams, P. D.; Winn, M. D.; Storoni, L. C.; Read, R. J. Phaser Crystallographic Software. J. Appl. Crystallogr. 2007, 40, 658-674.

(41) Murshudov, G. N.; Skubák, P.; Lebedev, A. A.; Pannu, N. S.; Steiner, R. A.; Nicholls, R. A.; Winn, M. D.; Long, F.; Vagin, A. A. REFMAC5 for the Refinement of Macromolecular Crystal Structures. Acta Crystallogr., Sect. D: Biol. Crystallogr. 2011, 67, 355-367.

(42) Afonine, P. V.; Grosse-Kunstleve, R. W.; Echols, N.; Headd, J. J.; Moriarty, N. W.; Mustyakimov, M.; Terwilliger, T. C.; Urzhumtsev, A.; Zwart, P. H.; Adams, P. D. Towards Automated Crystallographic Structure Refinement with Phenix.Refine. Acta Crystallogr., Sect. D: Biol. Crystallogr. 2012, 68, 352-367.

(43) Emsley, P.; Lohkamp, B.; Scott, W. G.; Cowtan, K. Features and Development of Coot. Acta Crystallogr., Sect. D: Biol. Crystallogr. 2010, 66, 486-501.

(44) Pfaffl, M. W. A new mathematical model for relative quantification in real-time RT-PCR. Nucleic Acids Res. 2001, 29, No. e45.

(45) Livak, K. J.; Schmittgen, T. D. Analysis of Relative Gene Expression Data Using Real-Time Quantitative PCR and the 2(-Delta Delta C(T)) Method. Methods 2001, 25, 402-408.

(46) Abràmoff, M. D.; Magalhães, P. J.; Ram, S. J. Image Processing with ImageJ. Biophot. Int. 2003, 11, 36-42. 